\title{
Validated imaging biomarkers as decision- making tools in clinical trials and routine practice: current status and recommendations from the EIBALL* subcommittee of the European Society of Radiology (ESR)
}

Nandita M. deSouza ${ }^{1 *}$, Eric Achten ${ }^{2}$, Angel Alberich-Bayarri ${ }^{3}$, Fabian Bamberg ${ }^{4}$, Ronald Boellaard ${ }^{5}$, Olivier Clément ${ }^{6}$, Laure Fournier $^{6}$, Ferdia Gallagher ${ }^{7}$, Xavier Golay ${ }^{8}$, Claus Peter Heussel ${ }^{9}$, Edward F. Jackson ${ }^{10}$,

Rashindra Manniesing ${ }^{11}$, Marius E. Mayerhofer ${ }^{12}$, Emanuele Neri ${ }^{13}$, James $\mathrm{O}^{\prime} \mathrm{Connor}^{14}$, Kader Karli Oguz ${ }^{15}$, Anders Persson ${ }^{16}$, Marion Smits ${ }^{17}$, Edwin J. R. van Beek ${ }^{18}$, Christoph J. Zech ${ }^{19}$ and European Society of Radiology ${ }^{20}$

\begin{abstract}
Observer-driven pattern recognition is the standard for interpretation of medical images. To achieve global parity in interpretation, semi-quantitative scoring systems have been developed based on observer assessments; these are widely used in scoring coronary artery disease, the arthritides and neurological conditions and for indicating the likelihood of malignancy. However, in an era of machine learning and artificial intelligence, it is increasingly desirable that we extract quantitative biomarkers from medical images that inform on disease detection, characterisation, monitoring and assessment of response to treatment. Quantitation has the potential to provide objective decisionsupport tools in the management pathway of patients. Despite this, the quantitative potential of imaging remains under-exploited because of variability of the measurement, lack of harmonised systems for data acquisition and analysis, and crucially, a paucity of evidence on how such quantitation potentially affects clinical decision-making and patient outcome. This article reviews the current evidence for the use of semi-quantitative and quantitative biomarkers in clinical settings at various stages of the disease pathway including diagnosis, staging and prognosis, as well as predicting and detecting treatment response. It critically appraises current practice and sets out recommendations for using imaging objectively to drive patient management decisions.
\end{abstract}

Keywords: Imaging biomarkers, Clinical decision making, Quantitation, Standardisation

\footnotetext{
* Correspondence: nandita.desouza@icr.ac.uk

*The European Imaging Biomarkers ALLiance (EIBALL) is a subcommittee of the ESR Research Committee. Its mission is to facilitate imaging biomarker development and standardisation and promote their use in clinical trials and in clinical practice by collaboration with specialist societies, international standards agencies and trials organisations. https://www.myesr.org/research/ esr-research-committee\#paragraph_grid_5924

${ }^{1}$ Cancer Research UK Imaging Centre, The Institute of Cancer Research and

The Royal Marsden Hospital, Downs Road, Sutton, Surrey SM2 5PT, UK

Full list of author information is available at the end of the article
} 


\section{Key points}

- Biomarkers derived from medical images inform on disease detection, characterisation and treatment response.

- Quantitative imaging biomarkers have potential to provide objective decision-support tools in the management pathway of patients.

- Measurement variability needs to be understood and systems for data acquisition and analysis harmonised before using quantitative imaging measurements to drive clinical decisions.

\section{Introduction}

Interpretation of medical images relies on visual assessment. Accumulated and learnt knowledge of anatomical and physiological variations determines recognition of appearances that are within "normal limits" and allows a pathological change in appearances outside these limits to be identified. Observer-driven pattern recognition dominates the way that imaging data are used in routine clinical practice (Fig. 1). A semi-quantitative approach to image analysis has been advocated in various scenarios. These use observer-based categorical scoring systems to classify images according to the presence or absence of certain features. Examples used widely in healthcare for clinical decision-making include reporting and data systems (RADS) [1, 2]. Increasingly, however, advancement in standardisation efforts, applications of analysis techniques to extract quantitative information and machine and deep learning techniques are transforming how medical images may be exploited.

In some clinical scenarios, automated quantitation may be more objective and accurate than manual assessment; thresholds can be applied above or below which a disease state is recognised and subsequent changes interpreted as clinically relevant [3]. Unlike biomaterials, images potentially can be transferred worldwide easily, cheaply and quickly for biomarker extraction in an automated, reproducible and blinded manner. Nevertheless, despite the substantial advantages of quantitation, very few quantitative imaging biomarkers are used in clinical decision-making due to several obstacles. Harmonisation of data acquisition and analysis is non-trivial. Lack of international standards without routine quality assurance (QA) and quality control (QC) processes results in poorly validated quantitative biomarkers that are subject to errors in interpretation [4-6]. This has profound implications for diagnosis (correct interpretation of the presence of the disease state) [7] and treatment decision-making (based on interpretation of response vs non-response) [8] and reduces the validity of combination biomarkers derived from hybrid (multi-modality) imaging systems. The imaging community needs to engage in delivering high-quality data for quantification and adoption of machine learning to ultimately exploit

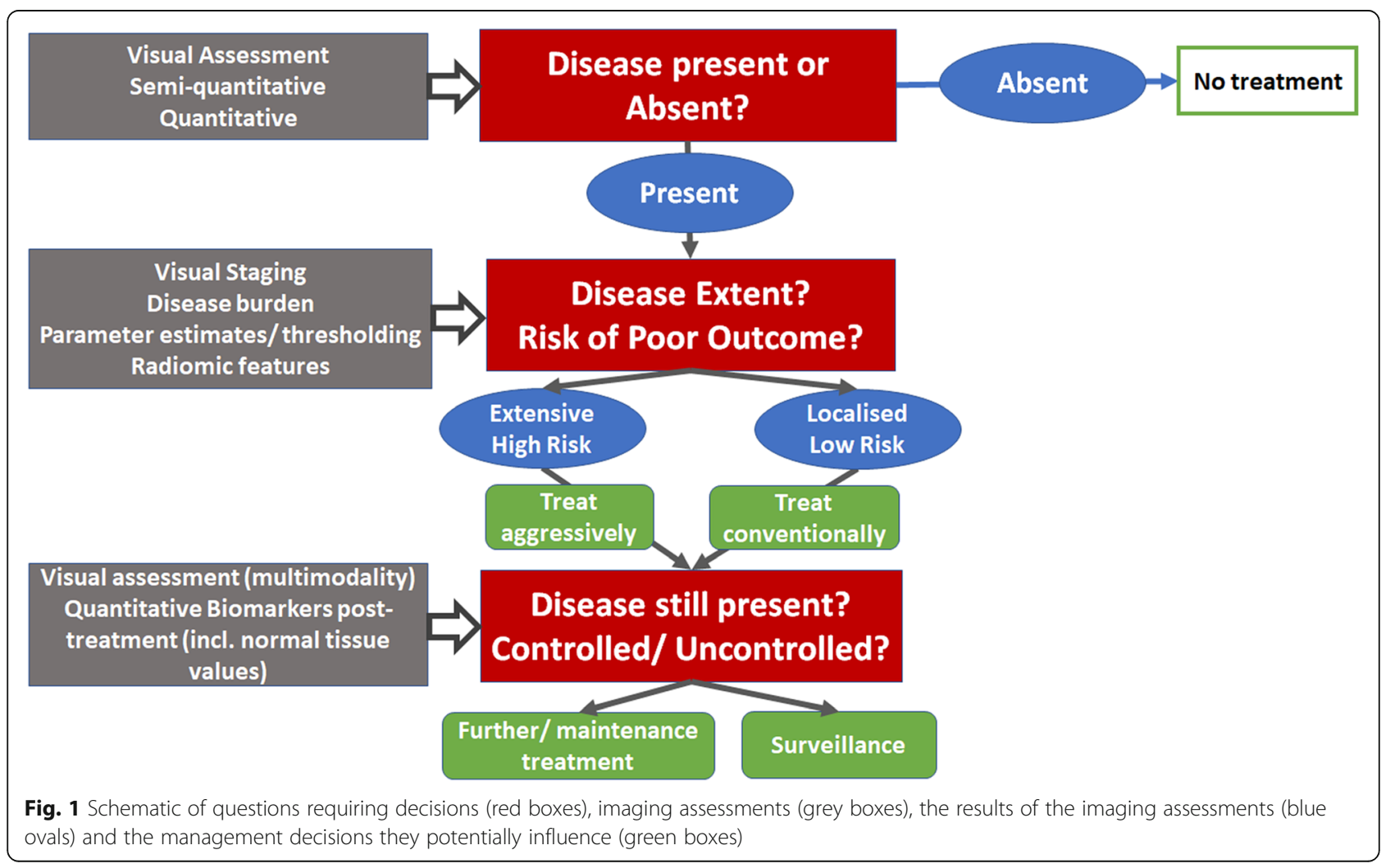


quantitative imaging information for clinical decisionmaking [9]. This manuscript describes the current evidence and future recommendations for using semiquantitative or quantitative imaging biomarkers as decision-support tools in clinical trials and ultimately in routine clinical practice.

\section{Validated imaging biomarkers currently used to support clinical decision-making}

The need for absolute quantitation (versus semi-quantitative assessment) in decision-making should be clearly established. Absolute quantitation is demanding and resource intensive because hardware and software differences across centres and instrumentation and their evolution impact the quality of quantified data. Rigorous on-going QA and QC are essential to support the validity and clinically acceptable repeatability of the measurement, and efforts are on-going within RSNA and the ESR and other academic societies. Critically also, definitive thresholds to confidently separate normal from pathological tissues based on absolute quantitative metrics often do not have wide applicability or acceptance.

\section{Semi-quantitative scoring systems}

Semi-quantitative readouts of scores based on an observer-recognition process are widely used because visual interpretation often has proven adequate and is linked to outcome. For example, MRI scoring systems for grading hypoxic-ischaemic injury in neonates using a combination of T1-weighted (T1W) imaging, T2-weighted (T2W) imaging and diffusion-weighted imaging (DWI) have shown that higher post-natal grades were associated with poorer neuro-developmental outcome [10]. In cervical spondylosis, grading of high T2-weighted (T2W) signal within the spinal cord has been related variably to disease severity and outcome $[11,12]$. In common diseases such as osteoarthritis, where follow-up scans to assess progression are vital in treatment decision-making, such scoring approaches also are useful [13]; web-based knowledge transfer tools using the developed scoring systems indicate good agreement between readers with both radiological and clinical background specialisms in interpreting the T2W MRI data [14]. Similar analyses have been extensively applied in diseases such as multiple sclerosis [15] and even to delineate the rectal wall from adjacent fibrosis [16]. In cancer imaging, ${ }^{18} \mathrm{FDG}$ PET/CT studies use the Deauville scale (liver and mediastinum uptake as reference) as the standard for response assessment in lymphoma [17]. Semi-quantitative scoring systems also form the basis of the breast imaging (BI)-RADS and prostate imaging (PI)-RADS systems in breast and prostate cancer respectively. Their wide adoption has led to spawning of similar classification scores for liver imaging (LI)-RADS [18-20], thyroid imaging (TI)-RADS [20] and bladder (vesicle imaging, VI)-RADS [21] tumours. Multiparametric MRI scores are also used for detection of recurrent gynaecological malignancy [22] and grading of renal cancer [23]. Manual assessment of lung nodule diameter and volume doubling time have reached a wide acceptance in the decision-making of incidental detection, screening [24] and prediction of response [25]. These parameters might be substituted or improved by artificial intelligence in the near future [26].

\section{Quantitative measures of size/volume}

The simplest quantitative measure used routinely is size. Size is linked to outcome in both non-malignant and malignant disease [27]. Ventricular size on echocardiography is robust and incorporated into large multicentre trials $[28,29]$ and into routine clinical care. Left ventricular ejection fraction (LVEF) is routinely extracted from both ultrasound and MRI measurements. In inflammatory diseases such as rheumatoid arthritis, where bone erosions are a central feature, assessment of the volume of disease on high-resolution $\mathrm{CT}$ provides a surrogate marker of disease severity [30] and is associated with the degree of physical impairment and mortality $[31,32]$. Yet these methods remain to be implemented in a clinical setting because intensive segmentation and post-processing resources are required. In cancer studies, unidimensional measurements (RECIST1.0 and 1.1) [27] are used for response because of the perceived robustness and simplicity of the measurement, although reproducibility is variable [33], resulting in uncertainty [34]. Although numerous studies have linked disease volume to outcome over decades of research [35-38], volume is not routinely documented in clinical reports because of the need for segmentation of irregularly shaped tumours. Volume is indicative of prognosis and response, for example in cervix cancer where evidence is strong [39]. In other cancer types, such as lung, metabolic active tumour volume on PET has a profound link to survival $[40,41]$. Metabolic active tumour volume also has proven to be a prognostic factor in several lymphoma studies [42] and is being explored as a biomarker for response to treatment [43-45]. The availability of automated volume segmentation at the point of reporting is essential for routine adoption.

\section{Extractable quantitative imaging biomarkers with potential to support clinical decision-making}

Quantitative imaging biomarkers that characterise tissue features (e.g. calcium, fat and iron deposition, cellularity, perfusion, hypoxia, diffusion, necrosis, metabolism, lung airspace density, fibrosis) can provide information that characterises a disease state and reflects histopathology. Multiple quantitative features can be incorporated into 
algorithms for recognising disease and its change over time (both natural course and in response to therapy). This involves an informatics style approach with data built from atlases derived from validated cases. Curation of anatomical databases annotated according to disease presence, phenotype and grade can then be used with the clinical data to build predictive models that act as decision-support tools. This has been proposed for brain data [46] but requires a collection of good quality validated data sets, carefully archived and curated. Harnessing the quantitative information contained in images with rigorous processes for acquisition and analysis, together with deep-learning algorithms such as has been demonstrated for brain ageing [47] and treatment response [48], will provide a valuable decision-support framework.

\section{Ultrasound}

Quantitation in ultrasound imaging has derived parameters related to cardiac output (left ventricular ejection fraction), tissue stiffness (elastography) and vascular perfusion (contrast-enhanced ultrasound) where parameters are related to blood flow. Ultrasound elastography is an emerging field; it has been shown to differentiate liver fibrosis [49], benign and malignant breast and prostate masses and invasive and intraductal breast cancers [50, 51]. It also has been explored for quantifying muscle stiffness in Parkinson's disease [52], where low interobserver variation and significant differences in Young's modulus between mildly symptomatic and healthy control limbs make it a useful assessment tool. Furthermore, it has shown acceptable inter-frame coefficient of variation for identifying unstable coronary plaques [53]. Blood flow quantified by power Doppler has potential as a bedside test for intramuscular blood flow in the muscular dystrophies [54]. Quantified parameters peak intensity (PI), mean transit time (MTT) and time to peak (TTP) are available from contrast-enhanced ultrasound, but rarely used because of competing studies with CT and MRI that also capture morphology.

\section{CT}

CT biomarkers are dependent on a single biophysical parameter, differential absorption of X-rays due to differences in tissue density, either on unenhanced scans or following administration of iodine-based contrast agent, which increases X-ray absorption in highly perfused tissues. Other developments have utilised tissue density as a parameter in multicentre trials for quantification of emphysema (COPDGene and SPIROMICS) [55-57] and interstitial pulmonary fibrosis (IPF-NET) [58] and for assessment of obstructive (reversible) airways disease $[59,60]$. The studies have made use of various open source and bespoke research software tools, but generally, these imaging-based biomarkers have been used to guide treatment [61, 62] and demonstrated direct correlation with outcomes and functional parameters [63]. Drawbacks include poor standardisation of imaging protocols (voltage, slice thickness, respiration, I.V. contrast, kernel size) and post-processing software [64], although many of these issues have been resolved using phantom quality assurance and specified imaging procedures for every CT system used in these studies $[65,66]$. Standardisation of instrumentation would simplify comparability between centres and enable longterm data acquisition consistency even after scanner updates [66]. In cardiac imaging, tissue density biomarkers using coronary artery calcium scoring have been extensively applied in large studies evaluating cardiac risk [67] and luminal size on coronary angiography used in outcome studies $[68,69]$. Dual-energy CT quantifies iodine concentration directly and is being investigated for characterising pulmonary nodules and pleural tumours $[70,71]$.

\section{MR including multiparametric data}

MRI is more versatile than US and CT because it can be manipulated to derive a number of parameters based on multiple intrinsic properties of tissue (including T1- and T2 relaxation times, proton density, diffusion, water-fat fraction) and how these are altered in the presence of other macromolecules (e.g. proteins giving rising to magnetisation transfer and chemical exchange transfer effects) and externally administered contrast agents (Gadolinium chelates). Perfusion metrics have also been derived with arterial spin labelling, which does not require externally administered agents [72]. The apparent diffusion coefficient (ADC) is the most widely used metric in oncology for disease detection [73, 74], prognosis [75] and response evaluation [76, 77]. Post-processing methods to derive absolute quantitation are extensively debated $[78,79]$, but the technique is robust with good reproducibility in multicentre, multivendor trials across tumour types [80]. Refinements to model intravascular incoherent motion (IVIM) and diffusion kurtosis are currently research tools. In cardiovascular MRI, there is a growing interest in quantifying T1 relaxation time, rather than just relying on its effect on image contrast; when combined with the use of contrast agents, T1 mapping allows investigation of interstitial remodeling in ischaemic and non-ischaemic heart disease [81]. T1 values are useful to distinguish inflammatory processes in the heart [82], multiple sclerosis in the central nervous system [83], iron and fat content in the liver $[84,85]$ and adrenal [86], which correlates with fibrosis scores on histology [87]. Multiparametric MRI biomarkers (T1 and proton density fat fraction) achieve a > 90\% AUC for differentiating patients with significant liver fibrosis and steatosis on histology [88] and are being supplemented by measurements of tissue stiffness (MR elastography) where a measurement repeatability 
Table 1 Imaging biomarkers for disease detection (semi-quantitative and quantitative) with examples of current evidence for their use that would support decision-making

\begin{tabular}{|c|c|c|c|c|c|c|c|}
\hline & Biomarker & $\begin{array}{l}\text { SemiQ/ } \\
\text { Q }\end{array}$ & Disease & $\begin{array}{l}\text { Question } \\
\text { answered }\end{array}$ & Utility of biomarker & Data from & $\begin{array}{l}\text { Potential decision } \\
\text { for }\end{array}$ \\
\hline \multirow[t]{6}{*}{$\begin{array}{l}\text { Non- } \\
\text { malignant } \\
\text { disease }\end{array}$} & $\begin{array}{l}\text { LVEF-US } \\
\text { LVEF-MRI }\end{array}$ & Q & $\begin{array}{l}\text { Cardiac } \\
\text { function } \\
{[28,29]} \\
\text { Cardiac } \\
\text { function }\end{array}$ & $\begin{array}{l}\text { Cardiac } \\
\text { output } \\
\text { Cardiac } \\
\text { output }\end{array}$ & $\begin{array}{l}\text { ICC US } 0.72 \text {, single centre } \\
\text { sensitivity } 69 \% \text { [29] } \\
\text { ICC MRI } 0.86, \text { correlation of } \\
\text { MRI and cineventriculography } \\
0.72 \text { [99] }\end{array}$ & $\begin{array}{l}\text { Single } \\
\text { centre US } \\
\text { Multicentre } \\
\text { MRI }[99,100]\end{array}$ & $\begin{array}{l}\text { Inotropes } \\
\text { Inotropes }\end{array}$ \\
\hline & $\begin{array}{l}\text { Renal volume- } \\
\text { US, CT, MRI }\end{array}$ & Q & Renal failure & $\begin{array}{l}\text { Mass of } \\
\text { parenchyma }\end{array}$ & $\begin{array}{l}\text { ICC on US } 0.64-0.86[101] \\
\text { Correlation of US with CT } \\
0.76-0.8 \text { [102] } \\
\text { Interobserver reproducibility } \\
\text { on MRI } 87-88 \% \text { [103] }\end{array}$ & Single centre & $\begin{array}{l}\text { Renal replacement, } \\
\text { safety and toxicity of } \\
\text { other pharmaceuticals }\end{array}$ \\
\hline & $\begin{array}{l}\text { Young's modulus } \\
\text { on elastography- } \\
\text { US }\end{array}$ & Q & $\begin{array}{l}\text { Thyroid [104], } \\
\text { breast [50] } \\
\text { and prostate } \\
\text { cancer [51] } \\
\text { Parkinson's } \\
\text { disease }\end{array}$ & $\begin{array}{l}\text { Tumour } \\
\text { presence } \\
\text { Muscle } \\
\text { stiffness }\end{array}$ & $\begin{array}{l}\text { Thyroid sensitivity } 80 \%, \\
\text { specificity } 95 \% \text { [104] } \\
\text { Breast AUC } 0.898 \text { for } \\
\text { conventional US, } 0.932 \\
\text { for shear wave elastography, } \\
\text { and } 0.982 \text { for combined } \\
\text { data [105] } \\
\text { Prostate sensitivity } 0.84, \\
\text { spec } 0.84 \text { [51] }\end{array}$ & $\begin{array}{l}\text { Thyroid, } \\
\text { breast: } \\
\text { single } \\
\text { centre } \\
\text { Prostate } \\
\text { meta-analysis }\end{array}$ & $\begin{array}{l}\text { Treatment with } \\
\text { surgery/radiotherapy/ } \\
\text { chemotherapy }\end{array}$ \\
\hline & $\begin{array}{l}\text { Lung tissue } \\
\text { density }\end{array}$ & Q & $\begin{array}{l}\text { Emphysema } \\
{[106,107] \text { and }} \\
\text { fibrosis [58] }\end{array}$ & $\begin{array}{l}\text { Airways } \\
\text { obstruction, } \\
\text { interstitial } \\
\text { lung disease } \\
\text { present }\end{array}$ & $\begin{array}{l}\text { Emphysema (density } \\
\text { assessment) influences } \\
\text { BODE (body mass index, } \\
\text { airflow obstruction, dyspnea } \\
\text { and exercise capacity) index. } \\
\text { Odds ratio of interstitial lung } \\
\text { abnormalities for reduced lung } \\
\text { capacity } 2.3\end{array}$ & $\begin{array}{l}\text { Multicentre } \\
\text { Single centre }\end{array}$ & $\begin{array}{l}\text { Surgery, valve and } \\
\text { drug treatment }\end{array}$ \\
\hline & $\begin{array}{l}\text { Fibrosis and } \\
\text { ground-glass } \\
\text { index on CT } \\
\text { lung }\end{array}$ & $\mathrm{SQ}$ & $\begin{array}{l}\text { Idiopathic } \\
\text { lung fibrosis }\end{array}$ & $\begin{array}{l}\text { Development of } \\
\text { inflammation } \\
\text { and fibrosis }\end{array}$ & $\begin{array}{l}\text { Mortality predicted by } \\
\text { pulmonary vascular volume } \\
\text { (HR } 1.23(1.08-1.40), p=0.001) \\
\text { and honeycombing (HR } 1.18 \\
(1.06-1.32), p=0.002)[108]\end{array}$ & Single centre & Drug treatment \\
\hline & $\mathrm{ADC} / \mathrm{pCT}$ & $\mathrm{SQ}$ & $\begin{array}{l}\text { Ischaemic } \\
\text { stroke }\end{array}$ & $\begin{array}{l}\text { Presence of } \\
\text { salvageable } \\
\text { tissue versus } \\
\text { infarct core }\end{array}$ & $\begin{array}{l}\text { Measure of infarct core/ } \\
\text { penumbra used for patient } \\
\text { stratification for research [109] }\end{array}$ & $\begin{array}{l}\text { Planned } \\
\text { multicentre }\end{array}$ & Treatment \\
\hline \multirow[t]{4}{*}{$\begin{array}{l}\text { Malignant } \\
\text { disease }\end{array}$} & $\begin{array}{l}\text { Lung RADS, } \\
\text { PanCan, NCCN } \\
\text { criteria }[110,111]\end{array}$ & $\mathrm{SQ}$ & Lung nodules & $\begin{array}{l}\text { Risk of } \\
\text { malignancy }\end{array}$ & $\begin{array}{l}\text { AUC for malignancy } \\
0.81-0.87[110]\end{array}$ & Multicentre & $\begin{array}{l}\text { Time period of } \\
\text { follow-up or surgery }\end{array}$ \\
\hline & $\begin{array}{l}\text { CT blood flow, } \\
\text { perfusion, } \\
\text { permeability } \\
\text { metrics }\end{array}$ & Q & $\begin{array}{l}\text { Malignant } \\
\text { neck lymph } \\
\text { nodes } \\
\text { Hepatocellular } \\
\text { cancer }\end{array}$ & $\begin{array}{l}\text { Tumour } \\
\text { presence }\end{array}$ & $\begin{array}{l}\text { Sensitivity } 0.73 \text {, specificity } \\
0.70[112] \\
\text { AUC } 0.75 \text {, sensitivity } 0.79 \\
\text { specificity } 0.75[113]\end{array}$ & $\begin{array}{l}\text { Single centre } \\
\text { Single centre }\end{array}$ & $\begin{array}{l}\text { Staging and } \\
\text { management } \\
\text { (surgery, radiotherapy } \\
\text { or chemotherapy) }\end{array}$ \\
\hline & $\begin{array}{l}\text { BI-RADS [114] } \\
\text { PI-RADS [115] } \\
\text { LI-RADS [116] }\end{array}$ & $\mathrm{SQ}$ & Cancer & $\begin{array}{l}\text { Risk of } \\
\text { malignancy }\end{array}$ & $\begin{array}{l}\text { PPV: BI-RADS0 } 14.1 \% \text {, } \\
\text { BI-RADS4 } 39.1 \% \text { and } \\
\text { BI-RADS5 } 92.9 \% \\
\text { PI-RADS2 pooled } \\
\text { sensitivity } 0.85, \\
\text { pooled specificity } 0.71 \\
\text { Pooled sensitivity for } \\
\text { malignancy } 0.93\end{array}$ & $\begin{array}{l}\text { Dutch breast } \\
\text { cancer } \\
\text { screening } \\
\text { programme } \\
\text { Meta-analysis } \\
\text { Systematic } \\
\text { review }\end{array}$ & $\begin{array}{l}\text { Staging and } \\
\text { management } \\
\text { stratification } \\
\text { (surgery, } \\
\text { radiotherapy, } \\
\text { chemotherapy, } \\
\text { combination) }\end{array}$ \\
\hline & $A D C$ & Q & $\begin{array}{l}\text { Cancer [117] } \\
\text { Liver lesions } \\
\text { [118] } \\
\text { Prostate } \\
\text { cancer [119] }\end{array}$ & $\begin{array}{l}\text { Tumour } \\
\text { presence }\end{array}$ & $\begin{array}{l}\text { Liver AUC 0.82-0.95 } \\
\text { Prostate AUC } 0.84\end{array}$ & $\begin{array}{l}\text { Single centre } \\
\text { Single centre }\end{array}$ & $\begin{array}{l}\text { Staging and } \\
\text { management } \\
\text { stratification } \\
\text { (surgery, } \\
\text { radiotherapy, } \\
\text { chemotherapy, } \\
\text { combination) }\end{array}$ \\
\hline
\end{tabular}


Table 1 Imaging biomarkers for disease detection (semi-quantitative and quantitative) with examples of current evidence for their use that would support decision-making (Continued)

\begin{tabular}{|c|c|c|c|c|c|c|}
\hline \multicolumn{7}{|l|}{ Disease detection } \\
\hline Biomarker & $\begin{array}{l}\text { SemiQ/ } \\
\text { Q }\end{array}$ & Disease & $\begin{array}{l}\text { Question } \\
\text { answered }\end{array}$ & Utility of biomarker & Data from & $\begin{array}{l}\text { Potential decision } \\
\text { for }\end{array}$ \\
\hline $\begin{array}{l}\text { Dynamic contrast } \\
\text { enhanced metrics } \\
\left(K^{\text {trans }}, K_{e p} \text { blood }\right. \\
\left.\text { flow, } V_{e}\right)\end{array}$ & Q & $\begin{array}{l}\text { Liver tumour } \\
\text { Recurrent } \\
\text { glioblastoma }\end{array}$ & & $\begin{array}{l}\text { Hepatocellular cancer } \\
\text { AUC } 0.85 \text {, sensitivity } 0.85 \text {, } \\
\text { specificity } 0.81[113] \\
\text { Brain- } K^{\text {trans }} \text { Accuracy } \\
86 \%[120]\end{array}$ & $\begin{array}{l}\text { Single centre } \\
\text { Single centre }\end{array}$ & Further treatment \\
\hline${ }^{18}$ FDG SUV & Q & $\begin{array}{l}\text { Cancer } \\
\text { Sarcoma [121] } \\
\text { Lung cancer } \\
{[105]}\end{array}$ & $\begin{array}{l}\text { Tumour } \\
\text { presence }\end{array}$ & $\begin{array}{l}\text { Sarcoma-sensitivity } \\
0.91 \text {, specificity } 0.85 \text {, } \\
\text { accuracy } 0.88 \\
\text { Lung-sensitivity } 0.68 \\
\text { to } 0.95 \text { depending on } \\
\text { histology }\end{array}$ & $\begin{array}{l}\text { Meta-analysis } \\
\text { Meta-analysis }\end{array}$ & $\begin{array}{l}\text { Staging and } \\
\text { management } \\
\text { stratification } \\
\text { (surgery, } \\
\text { radiotherapy, } \\
\text { chemotherapy, } \\
\text { combination) }\end{array}$ \\
\hline $\begin{array}{l}\text { Targeted radionuclides } \\
\text { [122] In-octreotide } \\
\text { [123] } \\
\text { [68]Ga DOTATOC and } \\
\text { [68]Ga DOTATATE } \\
\text { [124, 125] [68]Ga } \\
\text { PSMA [4] }\end{array}$ & Non-Q & Cancer & $\begin{array}{l}\text { Tumour } \\
\text { presence }\end{array}$ & $\begin{array}{l}\text { Sensitivity } 97 \% \text { and } \\
\text { specificity } 92 \% \text { for } \\
\text { octreotide }[126] \\
\text { Sensitivity } 100 \% \text { and } \\
\text { specificity } 100 \% \text { for } \\
\text { PSMA [127] }\end{array}$ & $\begin{array}{l}\text { Single centre } \\
\text { Single centre }\end{array}$ & $\begin{array}{l}\text { Validation remains } \\
\text { difficult because of } \\
\text { biopsying multiple } \\
\text { positive sites. }\end{array}$ \\
\hline
\end{tabular}

Biomarkers used visually in the clinic are given in italics, and those that are used quantitatively are in bold

Abbreviations: $A D C$ apparent diffusion coefficient, $A P T$ amide proton transfer, $A U C$ area under curve, BI-RADS breast imaging reporting and data systems, CBV cerebral blood volume, CoV coefficient of variation, $C R$ complete response, $C T$ computerised tomography, DCE dynamic contrast enhanced, $D F S$ disease-free survival, DOTATOC DOTA octreotitide, DOTATATE DOTA octreotate, DSC dynamic susceptibility contrast, ECG electro cardiogram, FDG fluorodeoxyglucose, FLT fluoro thymidine, $H R$ hazard ratio, $H U$ Hounsfield unit, ICC intraclass correlation, IQR interquartile range, $L V E F$ left ventricular ejection fraction, MRF magnetic resonance fingerprinting, MRI magnetic resonance imaging, MTR magnetisation transfer ratio, NCCN National Comprehensive Cancer Network, OS overall survival, $p C T$ perfusion computerised tomography, PERCIST positron emission tomography response criteria in solid tumours, $P D$ progressive disease, $P F S$ progression-free survival, $P P V$ positive predictive value, PI-RADS prostate imaging reporting and data systems, $P R$ partial response, $P S M A$ prostate-specific membrane antigen, $R E C I L$ response evaluation in lymphoma, RECIST response evaluation criteria in solid tumours, $R O C$ receiver operating characteristic, SD stable disease, SUV standardised uptake value, SWE shear wave elastography, US ultrasound

coefficient of $22 \%$ has been demonstrated in a metaanalysis [89]. Chemical exchange saturation transfer (CEST) MRI interrogates endogenous biomolecules with amide, amine and hydroxyl groups; exogenous CEST agents such as glucose provide quantitative imaging biomarkers of metabolism and perfusion. Quantitative CEST imaging shows promise in assessing cerebral ischaemia [90], lymphedema [91], osteoarthritis [92] and metabolism/pH of solid tumours [93]. However, the small signal requires higher field strength acquisition and substantial post-processing.

\section{Positron emission tomography (PET)-SUV metrics}

Quantitation of ${ }^{18} \mathrm{FDG}$ PET/CT studies is mainly performed by standardised uptake values (SUVs), although other metrics such as metabolic active tumour volume (MATV) and total lesion glycolysis are being introduced in studies and the clinic $[94,95]$. The most frequently used metric to assess the intensity of FDG accumulation in cancer lesions is, however, still the maximum SUV. SUV represents the tumour tracer uptake normalised for injected activity per kilogram body weight. SUV and any of the other PET quantitative metrics are affected by technical (calibration of systems, synchronisation of clocks and accurate assessment of injected ${ }^{18}$ FDG activity), physical (procedure, methods and settings used for image acquisition, image reconstruction and quantitative image analysis) and physiological factors (FDG kinetics and patient biology/physiology) [96]. To mitigate these factors, guidelines have been developed in order to standardise imaging procedures [96, 97] and to harmonise PET/CT system performance at a European level [97, 98]. Newer targeted PET agents are only assessed qualitatively on their distribution (Table 1).

\section{Radiomic signature biomarkers}

Radiomics describes the extraction and analysis of quantitative features from radiological images. The assumption is that radiomic features reflect pathophysiological processes expressed by other "omics", such as genomics, transcriptomics, metabolomics and proteomics [128]. Hundreds to thousands of radiomic features (mathematical descriptors of texture, heterogeneity or shape) can be extracted from a region or volume of interest (ROI/ VOI), derived manually or semi-automatically by a human operator, or automatically by a computer algorithm. The radiomic "signature" (summary of all features) is expected to be specific for a given patient, patient group, 
Table 2 Imaging biomarkers for disease characterisation (semi-quantitative and quantitative) with examples of current evidence for their use that would support decision-making

\begin{tabular}{|c|c|c|c|c|c|c|c|}
\hline & Biomarker & $\begin{array}{l}\text { SemiQ/ } \\
\text { Q }\end{array}$ & Disease & Question answered & Utility of biomarker & Data from & $\begin{array}{l}\text { Potential decision } \\
\text { for }\end{array}$ \\
\hline \multirow[t]{4}{*}{$\begin{array}{l}\text { Non- } \\
\text { malignant } \\
\text { disease }\end{array}$} & $\begin{array}{l}\text { Young's } \\
\text { modulus }\end{array}$ & Q & $\begin{array}{l}\text { Coronary } \\
\text { plaques [53] }\end{array}$ & Risk of rupture & $\begin{array}{l}\text { Reproducibility CoV 22\% vessel wall, } \\
19 \% \text { in plaque. AUC for focal neurology } \\
\text { Youngs modulus + degree }=0.78\end{array}$ & $\begin{array}{l}\text { Single } \\
\text { centre }\end{array}$ & $\begin{array}{l}\text { Stenting, coronary } \\
\text { bypass surgery }\end{array}$ \\
\hline & $\begin{array}{l}\text { Plaque } \\
\text { density, } \\
\text { vessel } \\
\text { luminal } \\
\text { diameter }\end{array}$ & Q & $\begin{array}{l}\text { Coronary } \\
\text { artery } \\
\text { stenosis }\end{array}$ & $\begin{array}{l}\text { Risk of plaque } \\
\text { rupture; risk of } \\
\text { significant cardiac } \\
\text { ischaemia, infarction, } \\
\text { death }\end{array}$ & $\begin{array}{l}\text { No luminal narrowing but with } \\
\text { coronary artery calcium (CAC) score }>0 \\
\text { had a 5-year mortality HR } 1.8 \\
\text { compared with those whose CACS }=0 \text {. } \\
\text { No luminal narrowing but CAC } \geq 100 \\
\text { had mortality risks similar to individuals } \\
\text { with non-obstructive coronary artery } \\
\text { disease [138] } \\
\text { CT angiography significantly better at } \\
\text { predicting events than stress echo/ECG } \\
\text { [68] } \\
\text { Coronary death/non-fatal myocardial } \\
\text { infarction was lower in patients with } \\
\text { stable angina receiving CT angiography } \\
\text { than in the standard-care group (HR }= \\
0.59 \text { ) [69] }\end{array}$ & $\begin{array}{l}\text { Multicentre } \\
\text { Multicentre } \\
\text { Multicentre }\end{array}$ & $\begin{array}{l}\text { Statins, stenting, } \\
\text { coronary bypass } \\
\text { surgery }\end{array}$ \\
\hline & ${ }^{18} \mathrm{~F}-\mathrm{Na}$ & SQ & $\begin{array}{l}\text { Aortic valve } \\
\text { disease } \\
\text { Coronary } \\
\text { plaque [139] } \\
\text { Acute events } \\
\text { from abdominal } \\
\text { aortic aneurysm }\end{array}$ & $\begin{array}{l}\text { Valve stenosis } \\
\text { present } \\
\text { Likelihood of plaque } \\
\text { rupture } \\
\text { Likelihood of } \\
\text { aneurysm rupture }\end{array}$ & $\begin{array}{l}\text { Reproducibility NaF uptake } 10 \% \text { [140] } \\
\text { Baseline } 18 \mathrm{~F}-\mathrm{NaF} \text { uptake correlated } \\
\text { closely with the change in calcium } \\
\text { score at } 1 \text { year [141] } \\
{ }^{18} \mathrm{~F}-\mathrm{NaF} \text { uptake (maximum tissue-to- } \\
\text { background ratio } 1.90 \text { [IQR } 1.61-2.17] \text { ) } \\
\text { associated with ruptured plaques and } \\
\text { those with high-risk features [142] } \\
\text { Aneurysms in the highest tertile of }{ }^{18} \mathrm{~F}- \\
\text { NaF uptake expanded } 2.5 \times \text { more } \\
\text { rapidly than those in the lowest tertile } \\
\text { and were } 3 \times \text { more likely to rupture } \\
\text { [143] }\end{array}$ & $\begin{array}{l}\text { Single } \\
\text { Multicentre }\end{array}$ & $\begin{array}{l}\text { Coronary stenting, } \\
\text { aneurysm stenting }\end{array}$ \\
\hline & MTR & Q & $\begin{array}{l}\text { Multiple } \\
\text { sclerosis }\end{array}$ & Disease progression & $\begin{array}{l}\text { MTR significantly correlates with T2 } \\
\text { lesion volume [144] } \\
\text { Grey matter MTR histogram peak } \\
\text { height and average lesion MTR } \\
\text { percentage change after } 12 \text { months } \\
\text { independent predictors of disability } \\
\text { worsening at } 8 \text { years [145] } \\
\text { Change in brain MTR specificity } 76.9 \% \\
\text { and PPV 59.1\% for Expanded Disability } \\
\text { Status Scale score deterioration [146] }\end{array}$ & $\begin{array}{l}\text { Multicentre } \\
\text { Single } \\
\text { centre } \\
\text { Single } \\
\text { centre }\end{array}$ & $\begin{array}{l}\text { Timing of } \\
\text { therapeutic } \\
\text { intervention }\end{array}$ \\
\hline \multirow[t]{3}{*}{$\begin{array}{l}\text { Malignant } \\
\text { disease }\end{array}$} & ${ }^{18}$ FDG-SUV & Q & $\begin{array}{l}\text { Cancer } \\
\text { Oesophageal } \\
\text { cancer }\end{array}$ & $\begin{array}{l}\text { Good or poor } \\
\text { prognosis tumour in } \\
\text { terms of PFS and OS }\end{array}$ & $\begin{array}{l}\text { Wide variation between individuals and } \\
\text { tumours [147] } \\
\text { Oesophageal cancer HR } 1.86 \text { for OS, } \\
2.52 \text { for DFS }[148]\end{array}$ & $\begin{array}{l}\text { Meta- } \\
\text { analysis }\end{array}$ & $\begin{array}{l}\text { Neoadjuvant or } \\
\text { adjuvant therapy } \\
\text { or treatment } \\
\text { modality } \\
\text { combinations }\end{array}$ \\
\hline & ${ }^{18}$ FLT-SUV & Q & Cancer & $\begin{array}{l}\text { High proliferative } \\
\text { activity present }\end{array}$ & $\begin{array}{l}\text { Sizeable overlap in values with normal } \\
\text { proliferating tissues [75] }\end{array}$ & $\begin{array}{l}\text { Review of } \\
\text { data from } \\
\text { single } \\
\text { centre } \\
\text { studies }\end{array}$ & $\begin{array}{l}\text { Neoadjuvant or } \\
\text { adjuvant therapy } \\
\text { or treatment } \\
\text { modality } \\
\text { combinations }\end{array}$ \\
\hline & $\begin{array}{l}\text { ADC } \\
\text { MRF (ADC, } \\
\text { T1 and T2) }\end{array}$ & $\begin{array}{l}\mathrm{Q} \\
\mathrm{Q} \\
\mathrm{Q}\end{array}$ & $\begin{array}{l}\text { Cancer, } \\
\text { correlates } \\
\text { with tumour } \\
\text { grade }\end{array}$ & $\begin{array}{l}\text { Risk of recurrence or } \\
\text { metastasis }\end{array}$ & $\begin{array}{l}\text { Area under ROC, sensitivity and } \\
\text { specificity of nADCmean for G3 } \\
\text { intrahepatic cholangiocarcinoma versus } \\
\text { G1+G2 were } 0.71,89.5 \% \text { and } 55.5 \% \\
{[149]} \\
\text { "Unfavourable" ADC in cervix cancer } \\
\text { predictive of disease-free survival (HR } \\
1.55)[150] \\
\text { ADC and T2 together give AUC of } 0.83\end{array}$ & $\begin{array}{l}\text { Single } \\
\text { centre } \\
\text { Meta- } \\
\text { analysis } \\
\text { Single } \\
\text { centre }\end{array}$ & $\begin{array}{l}\text { Need of biopsy or } \\
\text { other invasive } \\
\text { diagnosis } \\
\text { Neoadjuvant or } \\
\text { adjuvant therapy } \\
\text { Decision for } \\
\text { radical treatment } \\
\text { or active } \\
\text { surveillance }\end{array}$ \\
\hline
\end{tabular}


Table 2 Imaging biomarkers for disease characterisation (semi-quantitative and quantitative) with examples of current evidence for their use that would support decision-making (Continued)

\begin{tabular}{|c|c|c|c|c|c|c|}
\hline Biomarker & $\begin{array}{l}\text { SemiQ/ } \\
\text { Q }\end{array}$ & Disease & Question answered & Utility of biomarker & Data from & $\begin{array}{l}\text { Potential decision } \\
\text { for }\end{array}$ \\
\hline & & & & \multicolumn{3}{|l|}{$[151]$} \\
\hline DSC-MRI & $\begin{array}{l}\mathrm{SQ} \\
(\mathrm{rCBV})\end{array}$ & Brain cancer & Grading glioma & $\begin{array}{l}\text { AUC }=0.77 \text { for discriminating glioma } \\
\text { grades }|| \text { and III [152] }\end{array}$ & $\begin{array}{l}\text { Meta- } \\
\text { analysis }\end{array}$ & $\begin{array}{l}\text { Type and time of } \\
\text { intervention/ } \\
\text { treatment }\end{array}$ \\
\hline APT & Q & Glioma & Proliferation & $\begin{array}{l}\text { APT correlates with tumour grade and } \\
\text { Ki67 index [153] }\end{array}$ & $\begin{array}{l}\text { Single } \\
\text { centre }\end{array}$ & $\begin{array}{l}\text { Therapeutic } \\
\text { strategies }\end{array}$ \\
\hline $\begin{array}{l}\text { DCE-CT } \\
\text { parameters } \\
\text { Blood flow, } \\
\text { permeability }\end{array}$ & Q & $\begin{array}{l}\text { Rectal cancer } \\
\text { Lung cancer }\end{array}$ & & $\begin{array}{l}\text { Blood flow } 75 \% \text { accuracy for detecting } \\
\text { rectal tumours with lymph node } \\
\text { metastases [154] } \\
\text { CT permeability predicted survival } \\
\text { independent of treatment in lung } \\
\text { cancer [155] }\end{array}$ & $\begin{array}{l}\text { Single } \\
\text { centre } \\
\text { Single } \\
\text { centre }\end{array}$ & $\begin{array}{l}\text { Surgical } \\
\text { dissection, } \\
\text { adjuvant } \\
\text { radiotherapy } \\
\text { Adjuvant therapy }\end{array}$ \\
\hline $\begin{array}{l}\text { DCE-MRI } \\
\text { parameters }\end{array}$ & Q & $\begin{array}{l}\text { Cervix cancer } \\
\text { Endometrial } \\
\text { cancer } \\
\text { Rectal cancer } \\
\text { Breast cancer }\end{array}$ & $\begin{array}{l}\text { Risk of recurrence or } \\
\text { metastasis, survival }\end{array}$ & $\begin{array}{l}\text { Tumour volume with increasing signal } \\
\text { is a strong independent prognostic } \\
\text { factor for DFS and OS in cervical cancer } \\
{[156]} \\
\text { Low tumour blood flow and low rate } \\
\text { constant for contrast agent } \\
\text { intravasation }\left(k_{e p}\right) \text { associated with high- } \\
\text { risk histological subtype in endometrial } \\
\text { cancer [157] } \\
K^{\text {trans, }} \text { Kep and } V_{e} \text { significantly higher in } \\
\text { rectal cancers with distant metastasis } \\
\text { [158] } \\
\text { Ktrans, iAUCqualitative and ADC predict } \\
\text { low-risk breast tumors (AUC of } \\
\text { combined parameters 0.78) }\end{array}$ & $\begin{array}{l}\text { Single } \\
\text { centre } \\
\text { Single } \\
\text { centre } \\
\text { Single } \\
\text { centre } \\
\text { Single } \\
\text { centre }\end{array}$ & $\begin{array}{l}\text { Neoadjuvant, } \\
\text { adjuvant or } \\
\text { multimodality } \\
\text { treatment } \\
\text { strategies }\end{array}$ \\
\hline $\begin{array}{l}\text { Radiomic } \\
\text { signature } \\
{[159]}\end{array}$ & Q & $\begin{array}{l}\text { Multiple } \\
\text { tumour types } \\
{[160,161]}\end{array}$ & $\begin{array}{l}\text { Tumour with good } \\
\text { or poor prognosis }\end{array}$ & $\begin{array}{l}\text { Data endpoints, feature selection } \\
\text { techniques and classifiers were } \\
\text { significant factors in affecting predictive } \\
\text { accuracy in lung cancer [162] } \\
\text { Radiomic signature ( } 24 \text { selected } \\
\text { features) is significantly associated with } \\
\text { LN status in colorectal cancer [163] }\end{array}$ & $\begin{array}{l}\text { Single } \\
\text { centre } \\
\text { Single } \\
\text { centre }\end{array}$ & $\begin{array}{l}\text { Neoadjuvant or } \\
\text { adjuvant } \\
\text { treatment, } \\
\text { immunotherapy } \\
\text { Lymph node } \\
\text { dissection, } \\
\text { adjuvant } \\
\text { treatment }\end{array}$ \\
\hline
\end{tabular}

Biomarkers used visually in the clinic are given in italics, and those that are used quantitatively are in bold

Abbreviations: $A D C$ apparent diffusion coefficient, $A P T$ amide proton transfer, $A U C$ area under curve, $B I-R A D S$ breast imaging reporting and data systems, $C B V$ cerebral blood volume, CoV coefficient of variation, $C R$ complete response, $C T$ computerised tomography, DCE dynamic contrast enhanced, $D F S$ disease-free survival, DOTATOC DOTA octreotitide, DOTATATE DOTA octreotate, DSC dynamic susceptibility contrast, ECG electro cardiogram, FDG fluorodeoxyglucose, FLT fluoro thymidine, HR hazard ratio, HU Hounsfield unit, ICC intraclass correlation, IQR interquartile range, $L V E F$ left ventricular ejection fraction, MRF magnetic resonance fingerprinting, MRI magnetic resonance imaging, MTR magnetisation transfer ratio, NCCN National Comprehensive Cancer Network, OS overall survival, PCT perfusion computerised tomography, PERCIST positron emission tomography response criteria in solid tumours, $P D$ progressive disease, $P F S$ progression-free survival, PPV positive predictive value, PI-RADS prostate imaging reporting and data systems, $P R$ partial response, $P S M A$ prostate-specific membrane antigen, RECIL response evaluation in lymphoma, RECIST response evaluation criteria in solid tumours, ROC receiver operating characteristic, SD stable disease, SUV standardised uptake value, SWE shear wave elastography, US ultrasound

tissue or disease $[129,130]$ : it depends on the type of imaging data (CT, MRI, PET) and is influenced by image acquisition parameters (e.g. resolution, reconstruction algorithm, repetition/echo times for MRI), hardware (e.g. scanner model, coils), VOI/ROI segmentation [131] and image artifacts.

Unlike biopsies, radiomic analyses, although not tissue specific, capture heterogeneity across the entire volume [132], potentially making them more indicative of therapy response, resistance and survival. They may be therefore better suited to decision support in terms of treatment selection and risk stratification. Current radiomics research in X-ray mammography [133] and cross- sectional imaging (lung, head and neck, prostate, GI tract, brain) has shown promising results [134], leading to extrapolation in non-malignant disease. Image quality optimisation and standardisation of data acquisition are mandatory for widespread application. At present, individual research groups derive differing versions of a similar signature and there is a tendency to change the signature from study to study. Since radiomic signatures are typically multi-dimensional data, they are an ideal input for advanced machine learning techniques, such as artificial neural networks, especially when big multicentric datasets are available. Early reports from multicentre trials indicate that reproducibility of feature 
Table 3 Imaging biomarkers for disease response assessment (semi-quantitative and quantitative) with examples of current evidence for their use that would support decision-making

\begin{tabular}{|c|c|c|c|c|c|c|c|}
\hline & Biomarker & $\begin{array}{l}\text { SemiQ/ } \\
\text { Q }\end{array}$ & Disease & Question answered & Utility of biomarker & Data from & $\begin{array}{l}\text { Potential } \\
\text { decision for }\end{array}$ \\
\hline \multirow[t]{2}{*}{$\begin{array}{l}\text { Non- } \\
\text { malignant } \\
\text { disease }\end{array}$} & $\begin{array}{l}\text { Volumetric high } \\
\text { resolution CT density } \\
\text { (quantitative interstitial } \\
\text { lung disease, QILD) }\end{array}$ & Q & Scleroderma & $\begin{array}{l}\text { Response to } \\
\text { cyclophosphamide }\end{array}$ & $\begin{array}{l}\text { 24-month changes in QILD } \\
\text { scores in the whole lung } \\
\text { correlated significantly } \\
24-\text { month changes in } \\
\text { forced vital capacity } \\
(\rho=-0.37) \text {, diffusing } \\
\text { capacity }(\rho=-0.22) \\
\text { and breathlessness } \\
(\rho=-0.26)[164]\end{array}$ & $\begin{array}{l}\text { Single } \\
\text { centre }\end{array}$ & $\begin{array}{l}\text { Continue, } \\
\text { change or } \\
\text { stop treatment }\end{array}$ \\
\hline & $\begin{array}{l}\text { Left Ventricular } \\
\text { ejection fraction LVEF }\end{array}$ & Q & $\begin{array}{l}\text { Pulmonary } \\
\text { hypertension } \\
\text { Myocardial } \\
\text { ischaemia/ } \\
\text { infarction }\end{array}$ & $\begin{array}{l}\text { Right and left } \\
\text { cardiac sufficiency } \\
\text { Improvement in } \\
\text { cardiac function }\end{array}$ & $\begin{array}{l}\text { Increases in 6-min walk } \\
\text { distance were significant } \\
\text { correlated with change in } \\
\text { right ventricular ejection } \\
\text { fraction and left ventricular } \\
\text { end-diastolic volume [165] } \\
\text { Monitoring cardiac } \\
\text { function [166] }\end{array}$ & $\begin{array}{l}\text { Multicentre } \\
\text { Multicentre }\end{array}$ & $\begin{array}{l}\text { Continue, } \\
\text { change or } \\
\text { stop treatment }\end{array}$ \\
\hline \multirow[t]{8}{*}{$\begin{array}{l}\text { Malignant } \\
\text { disease }\end{array}$} & $\begin{array}{l}\text { RECIST/morphological } \\
\text { volume }\end{array}$ & Q & Cancer & Response & $\begin{array}{l}\text { Current guidelines for } \\
\text { response assessment [167] }\end{array}$ & Multicentre & $\begin{array}{l}\text { Continue, } \\
\text { change or } \\
\text { stop treatment }\end{array}$ \\
\hline & $\begin{array}{l}\text { PERCIST/metabolic } \\
\text { volume [168] }\end{array}$ & Q & Cancer & Response & $\begin{array}{l}\text { Current guidelines for } \\
\text { response assessment }\end{array}$ & Multicentre & $\begin{array}{l}\text { Continue, } \\
\text { change or } \\
\text { stop treatment }\end{array}$ \\
\hline & $\begin{array}{l}\text { Scoring systems for } \\
\text { disease burden }\end{array}$ & $\mathrm{SQ}$ & $\begin{array}{l}\text { Multiple } \\
\text { sclerosis } \\
\text { Rheumatoid } \\
\text { arthritis }\end{array}$ & $\begin{array}{l}\text { Reduction in } \\
\text { disease burden }\end{array}$ & $\begin{array}{l}\text { Effects on MRI lesions over } \\
6-9 \text { months predict the } \\
\text { effects on relapses at } \\
12-24 \text { months) [169] } \\
\text { International consensus on } \\
\text { scoring system [170] }\end{array}$ & $\begin{array}{l}\text { Meta- } \\
\text { analysis } \\
\text { Review }\end{array}$ & $\begin{array}{l}\text { Continue, } \\
\text { change or } \\
\text { stop therapy }\end{array}$ \\
\hline & DSC-MRI & $\begin{array}{l}\mathrm{SQ} \\
(\mathrm{rCBV})\end{array}$ & Brain cancer & $\begin{array}{l}\text { Differentiation of } \\
\text { treatment effects } \\
\text { and tumour } \\
\text { progression }\end{array}$ & $\begin{array}{l}\text { In } 2 \text { meta-analyses MRI had } \\
\text { high pooled sensitivities and } \\
\text { specificities: } 87 \%(95 \% \mathrm{Cl} \text {, } \\
0.82-0.91) \text { to } 90 \%(95 \% \mathrm{Cl}, \\
0.85-0.94) \text { sensitivity and } 86 \% \\
(95 \% \mathrm{Cl}, 0.77-0.91) \text { to } 88 \% \\
(95 \% \mathrm{Cl}, 0.83-0.92) \text { specificity } \\
{[171,172]}\end{array}$ & $\begin{array}{l}\text { Meta- } \\
\text { analysis }\end{array}$ & $\begin{array}{l}\text { Decision to } \\
\text { treat }\end{array}$ \\
\hline & ${ }^{18}$ F FDG-SUV $\max [173]$ & Q & $\begin{array}{l}\text { Multiple } \\
\text { cancer types }\end{array}$ & $\begin{array}{l}\text { Response } \\
\text { to therapy }\end{array}$ & $\begin{array}{l}\text { Rectal cancer-pooled } \\
\text { sensitivity, 73\%; pooled } \\
\text { specificity, 77\%; pooled } \\
\text { AUC, } 0.83 \text { [174] } \\
\text { Intratreatment low SUV } \max \\
\text { (persistent low or decrease } \\
\text { of }^{18} \text { F-FDG uptake) predictive } \\
\text { of loco-regional control in } \\
\text { head and neck cancer [175] }\end{array}$ & $\begin{array}{l}\text { Meta- } \\
\text { analysis } \\
\text { Meta- } \\
\text { analysis }\end{array}$ & $\begin{array}{l}\text { Continue, } \\
\text { change or } \\
\text { stop therapy }\end{array}$ \\
\hline & $\begin{array}{l}\text { Deauville or RECIL score } \\
\text { on }{ }^{18} \text { F-FDG-PET }\end{array}$ & SQ & Lymphoma & $\begin{array}{l}\text { CR, PR, SD or } \\
\text { PD }[176]\end{array}$ & $\begin{array}{l}\text { Assessment of tumour burden } \\
\text { in lymphoma clinical trials can } \\
\text { use the sum of longest diameters } \\
\text { of a maximum of three target } \\
\text { lesions [177] }\end{array}$ & Multicentre & $\begin{array}{l}\text { Continue, } \\
\text { change or } \\
\text { stop therapy }\end{array}$ \\
\hline & $\begin{array}{l}\text { Targeted agents } \\
\text { HER2 } \\
\text { PSMA }\end{array}$ & SQ & $\begin{array}{l}\text { Breast cancer } \\
{[178]} \\
\text { Prostate cancer } \\
{[179]}\end{array}$ & $\begin{array}{l}\text { Reduction in } \\
\text { tumour cells } \\
\text { expressing } \\
\text { these antigens }\end{array}$ & $\begin{array}{l}\text { Tumour receptor specific } \\
\text { Effects of treatment on } \\
\text { receptor expression }\end{array}$ & $\begin{array}{l}\text { Single } \\
\text { centre } \\
\text { studies, } \\
\text { review }\end{array}$ & $\begin{array}{l}\text { Continue, } \\
\text { change or } \\
\text { stop therapy }\end{array}$ \\
\hline & $A D C[117]$ & $\begin{array}{l}\mathrm{SQ} \\
\mathrm{Q}\end{array}$ & $\begin{array}{l}\text { Rectal cancer } \\
\text { Breast cancer }\end{array}$ & $\begin{array}{l}\text { Response to } \\
\text { neoadjuvant } \\
\text { chemotherapy } \\
\text { Response to } \\
\text { neoadjuvant } \\
\text { chemotherapy }\end{array}$ & $\begin{array}{l}\text { Additional value in both the } \\
\text { prediction and detection of } \\
\text { (complete) response to therapy } \\
\text { compared with conventional } \\
\text { sequences alone [180] } \\
\text { After } 12 \text { weeks of therapy, }\end{array}$ & $\begin{array}{l}\text { Review } \\
\text { Multicentre }\end{array}$ & $\begin{array}{l}\text { Continue, } \\
\text { change or } \\
\text { stop therapy, } \\
\text { proceed to } \\
\text { surgery }\end{array}$ \\
\hline
\end{tabular}


Table 3 Imaging biomarkers for disease response assessment (semi-quantitative and quantitative) with examples of current evidence for their use that would support decision-making (Continued)

\begin{tabular}{|c|c|c|c|c|c|c|}
\hline Biomarker & $\begin{array}{l}\text { SemiQ/ } \\
\text { Q }\end{array}$ & Disease & Question answered & Utility of biomarker & Data from & $\begin{array}{l}\text { Potential } \\
\text { decision for }\end{array}$ \\
\hline & & & & $\begin{array}{l}\text { change in } A D C \text { predicts } \\
\text { complete pathologic } \\
\text { response to neoadjuvant } \\
\text { chemotherapy (AUC }=0.61 \text {, } \\
p=0.013 \text { ) }[181]\end{array}$ & & \\
\hline $\begin{array}{l}\text { CT perfusion/blood } \\
\text { flow }\end{array}$ & Q & $\begin{array}{l}\text { Oesophageal } \\
\text { cancer }\end{array}$ & $\begin{array}{l}\text { Response to } \\
\text { chemoradiotherapy }\end{array}$ & $\begin{array}{l}\text { Multivariate analysis } \\
\text { identified blood flow } \\
\text { as a significant } \\
\text { independent predictor } \\
\text { of response [182] }\end{array}$ & $\begin{array}{l}\text { Single } \\
\text { centre }\end{array}$ & $\begin{array}{l}\text { Further } \\
\text { treatment }\end{array}$ \\
\hline DCE-MR parameters & Q & $\begin{array}{l}\text { Multiple } \\
\text { cancer types }\end{array}$ & $\begin{array}{l}\text { Response to } \\
\text { therapy }\end{array}$ & $\begin{array}{l}\text { Particular benefit in } \\
\text { assessing therapy } \\
\text { response to } \\
\text { antiangiogenic } \\
\text { agents [183] }\end{array}$ & Review & $\begin{array}{l}\text { Change } \\
\text { therapeutic } \\
\text { strategy }\end{array}$ \\
\hline CT density HU & Q & $\begin{array}{l}\text { Gastrointestinal } \\
\text { stromal tumours }\end{array}$ & $\begin{array}{l}\text { Response to } \\
\text { chemotherapy }\end{array}$ & $\begin{array}{l}\text { Decrease in tumour } \\
\text { density of }>15 \% \text { on } \\
\text { CT had a sensitivity } \\
\text { of } 97 \% \text { and a specificity } \\
\text { of } 100 \% \text { in identifying } \\
\text { PET responders versus } \\
52 \% \text { and } 100 \% \text { by } \\
\text { RECIST [184] }\end{array}$ & & $\begin{array}{l}\text { Continue, } \\
\text { change or } \\
\text { stop therapy }\end{array}$ \\
\hline
\end{tabular}

Biomarkers used visually in the clinic are given in italics, and those that are used quantitatively are in bold

Abbreviations: $A D C$ apparent diffusion coefficient, $A P T$ amide proton transfer, $A U C$ area under curve, BI-RADS breast imaging reporting and data systems, $C B V$ cerebral blood volume, CoV coefficient of variation, $C R$ complete response, $C T$ computerised tomography, DCE dynamic contrast enhanced, DFS disease-free survival, DOTATOC DOTA octreotitide, DOTATATE DOTA octreotate, DSC dynamic susceptibility contrast, ECG electro cardiogram, FDG fluorodeoxyglucose, FLT fluoro thymidine, HR hazard ratio, HU Hounsfield unit, ICC intraclass correlation, IQR interquartile range, LVEF left ventricular ejection fraction, $M R F$ magnetic resonance fingerprinting, $M R I$ magnetic resonance imaging, MTR magnetisation transfer ratio, NCCN National Comprehensive Cancer Network, OS overall survival, $p C T$ perfusion computerised tomography, PERCIST positron emission tomography response criteria in solid tumours, $P D$ progressive disease, $P F S$ progression-free survival, $P P V$ positive predictive value, $P I-R A D S$ prostate imaging reporting and data systems, $P R$ partial response, PSMA prostate-specific membrane antigen, RECIL response evaluation in lymphoma, RECIST response evaluation criteria in solid tumours, ROC receiver operating characteristic, SD stable disease, SUV standardised uptake value, SWE shear wave elastography, US ultrasound

Table 4 Recommendations for the use of quantitative imaging biomarkers as decision-support tools

\begin{tabular}{ll}
\hline Recommendation & Current evidence \\
\hline $\begin{array}{l}\text { Consider need for quantitation } \\
\text { in relation to the decision being } \\
\text { made }\end{array}$ & $\begin{array}{l}\text { Semi-quantitative imaging biomarkers are } \\
\text { successfully used in many clinical pathways. }\end{array}$ \\
$\begin{array}{ll}\text { Use validated IB methodology for } \\
\text { semi-quantitative and quantitative } \\
\text { measures }\end{array}$ & $\begin{array}{l}\text { Many single and multicentre trials validating } \\
\text { quantitative imaging biomarkers with clinical } \\
\text { Establish evidence on the use of } \\
\text { quantitation by inclusion into } \\
\text { clinical trials }\end{array}$ \\
& $\begin{array}{l}\text { Clinical trials are usually planned by non-imagers. } \\
\text { Integration of imaging biomarkers into trials is } \\
\text { dependent on what is available routinely to }\end{array}$ \\
& non-imagers in the clinic, rather than exploiting \\
an imaging technique to its optimal potential.
\end{tabular}

Validate against pathology or clinical outcomes to make imaging a "virtual biopsy"

Select appropriate quality assured quantitative IB

Open-source interchange kernel
Several major databanks hold imaging and

clinical or pathology data

- CaBIG (USA)

- UK MRC Biobank (UK)

- German National Cohort Study (Germany)

Trials with embedded QA/QC procedures have indicated good reproducibility of quantitative imaging biomarkers (e.g. EU iMi QulC:ConCePT project)

Low comparability between image-derived biomarkers if hardware and software of different manufacturers are used.

\section{Action needed}

- Classification systems retain a subjective element

that could benefit from standardisation and refinement.

- Development of automated and thresholding would enable more quantitative assessments

- Harmonisation of methodology

- Standardised reporting systems

- Inventory of imaging biomarkers accessible through a web-based portal would inform the inclusion and utilisation of imaging biomarkers within trials (The European Imaging Biomarkers Alliance initiative).

- Certified biomarkers conforming to set standards (Quantitative Imaging Biomarkers Alliance initiative)

- Large data collection for validation of imaging and pathology

- Curation in imaging biobanks

- Ensure curation and archiving of longitudinal imaging data with outcomes within trials

- Harmonisation of image acquisition and post-processing over manufacturers 
selection is good when extracted from CT [135] as well as MRI [136] data.

\section{Selecting and translating appropriate imaging biomarkers to support clinical decision-making}

Automated quantitative assessments rather than scoring systems are easier to incorporate into artificial intelligence systems. For this, threshold values need to be established and a probability function of the likelihood of disease vs. no disease derived from the absolute quantitation (e.g. bone density measurements) [137]. Alternatively, ratios of values to adjacent healthy tissue can be used to recognise disease. Similarly, for prognostic information, thresholds established from large databases will define action limits for altering management based on the likelihood of a good or poor outcome predicted by imaging data. This will enable the clinical community to move towards using imaging as a "virtual biopsy". The current evidence for use of quantitative imaging biomarkers for diagnostic and prognostic purposes is given in Tables 1 and 2 respectively.

For assessing treatment response (Table 3), the key element in biomarker selection relates to the type of treatment and expected pathological response. For nontargeted therapies, tissue necrosis to cytotoxic agents is expected, so biomarkers that read-out on increased free water (CT Hounsfield units) or reduced cell density (ADC) are most useful. With specific targeted agents (e.g. antiangiogenics), specific biomarker read-outs (perfusion metrics by US, CT or MRI) are more appropriate [185]. Both non-targeted and targeted agents shut down tumour metabolism, so that in glycolytic tumours, FDG metrics are exquisitely sensitive [186]. Distortion and changes following surgery, or changes in the adjacent normal tissue following radiotherapy [122], reduce quantitative differences between irradiated non-malignant and residual malignant tissue, so must be taken into account [187]. In multicentre trials, it is also crucial to establish the repeatability of the quantitative biomarker across multiple sites and vendor platforms for response interpretation [4].

\section{Advancing new quantitative imaging biomarkers as decision-support tools to clinical practice}

To become clinically useful, biomarkers must be rigorously evaluated for their technical performance, reproducibility, biological and clinical validity, and cost-effectiveness [6]. Table 4 gives current recommendations for use of quantitative biomarkers as decision support tools.

Technical validation establishes whether a biomarker can be derived reliably in different institutions (comparability) and on widely available platforms. Provision must be made if specialist hardware or software is required, or if a key tracer or contrast agent is not licensed for clinical use. Reproducibility, a mandatory requirement, is very rarely demonstrated in practice [188] because inclusion of a repeat baseline study is resource and time intensive for both patients and researchers. Multicentre technical validation using standardised protocols may occur after initial biological validation (evidence that known perturbations in biology alter the imaging biomarker signal in a way that supports the measurement characteristics assigned to the biomarker). Subsequent clinical validation, showing that the same relationships are observed in patients, may then occur in parallel to multicentre technical validation.

Once a biomarker is shown to have acceptable technical, biological and clinical validation, a decision must be made to qualify the biomarker for a specific purpose or use. Increasingly, the role of imaging in the context of other non-imaging biomarkers needs to be considered as part of a multiparametric healthcare assessment. For example, circulating biomarkers such as circulating tumour DNA are often more specific at detecting disease but do not localise or stage tumours. The integration of imaging biomarkers with tissue and liquid biomarkers is likely to replace many traditional and more simplistic approaches to decision-support systems that are used currently.

The cost-effectiveness of a biomarker is increasingly important in financially restricted healthcare systems where value-based care is increasingly considered [189]. However, the information may be derived from scans done as part of the patients' clinical work-up. Nevertheless, additional imaging/image processing is expensive compared to liquid- and tissue-based biomarkers. Costs can be offset against the cost saving from the unnecessary use of expensive but ineffective novel and targeted drugs. Health economic assessment is therefore an important part of translating a new biomarker into routine clinical practice. In an era of artificial intelligence, where radiologists are faced with an ever-increasing volume of digital data, it makes sense to increase our efforts at utilising validated, quantified imaging biomarkers as key elements in supporting management decisions for patients.

\section{Abbreviations}

ADC: Apparent diffusion coefficient; APT: Amide proton transfer; AUC: Area under curve; CBV: Cerebral blood volume; CEST: Chemical exchange saturation transfer; CoV: Coefficient of variation; CR: Complete response; $C T$ : Computerised tomography; DCE: Dynamic contrast enhanced; DFS: Disease-free survival; DOTATOC: DOTA octreotitide; DOTATATE: DOTAoctreotate; DSC: Dynamic susceptibility contrast; DWI: Diffusion-weighted imaging; ECG: Electrocardiogram; ESR: European Society of Radiology; FDG: Fluorodeoxyglucose; FLT: Fluorothymidine; HR: Hazard ratio; HU: Hounsfield unit; ICC: Intraclass correlation; IPF: Interstitial pulmonary fibrosis; IQR: Interquartile range; LVEF: Left ventricular ejection fraction; MATV: Metabolic active tumour volume; MRF: Magnetic resonance fingerprinting; MRI: Magnetic resonance imaging; MTR: Magnetisation transfer ratio; MTT: Mean transit time; NCCN: National Comprehensive Cancer Network; OS: Overall survival; PCT: Perfusion computerised tomography; PERCIST: Positron emission tomography response criteria in solid tumours; PD: Progressive disease; PFS: Progression free survival; PPV: Positive predictive 
value; PI: Peak intensity; PR: Partial response; PSMA: Prostate specific membrane antigen; QA: Quality assurance; QC: Quality control; RADS: Reporting and data systems ( $\mathrm{Bl}$, breast imaging; LI, liver imaging; Pl, prostate imaging; $\mathrm{TI}$, thyroid imaging; $\mathrm{VI}$, vesicle imaging); RECIL: Response evaluation in lymphoma; RECIST: Response evaluation criteria in solid tumours; ROC: Receiver operating characteristic; ROI: Region of interest; RSNA: Radiological Society of North America; SD: Stable disease; SUV: Standardised uptake value; SWE: Shear wave elastography; TTP: Time to peak; US: Ultrasound; VOI: Voxel of interest

\section{Acknowledgements}

This paper was reviewed and endorsed by the ESR Executive Council in March 2019

\section{Authors' contributions}

All authors have contributed to the conception of the work, have drafted the work and have approved the submitted final version of the manuscript.

\section{Authors' information}

All authors are either past or current members of the European Biomarkers Alliance subcommittee.

\section{Funding}

None declared for this work.

\section{Availability of data and materials}

Not applicable

\section{Ethics approval and consent to participate}

Not applicable

\section{Consent for publication}

Not applicable

\section{Competing interests}

The authors declare that they have no competing interests.

\section{Author details}

'Cancer Research UK Imaging Centre, The Institute of Cancer Research and The Royal Marsden Hospital, Downs Road, Sutton, Surrey SM2 5PT, UK. ${ }^{2}$ Ghent University Hospital, Ghent, Belgium. ${ }^{3}$ QUIBIM SL / La Fe Health Research Institute, Valencia, Spain. ${ }^{4}$ Department of Radiology, University of Freiburg, Freiburg im Breisgau, Germany. ${ }^{5}$ VU University Medical Center, Amsterdam, The Netherlands. ${ }^{6}$ Hopital Européen Georges Pompidou, Paris, France. ${ }^{7}$ University of Cambridge, Cambridge, UK. ${ }^{8}$ UCL Institute of Neurology, London, UK. ${ }^{9}$ Universitätsklinik Heidelberg, Translational Lung Research Center (TLRC), German Center for Lung Research (DZL), University of Heidelberg, Im Neuenheimer Feld 156, 69120 Heidelberg, Germany.

${ }^{10}$ University of Wisconsin School of Medicine and Public Health, Madison, WI, USA. ${ }^{11}$ Department of Radiology and Nuclear Medicine, Radboud University Medical Center, Geert Grooteplein 10, 6525, GA, Nijmegen, The Netherlands. ${ }^{12}$ Medical University Vienna, Vienna, Austria. ${ }^{13}$ Department of Translational Research, University of Pisa, Pisa, Italy. ${ }^{14}$ Division of Cancer Sciences, University of Manchester, Manchester, UK. ${ }^{15}$ Hacettepe University Hospitals, Ankara, Turkey. ${ }^{16}$ Linköpings Universitet, Linköping, Sweden. ${ }^{17}$ Department of Radiology and Nuclear Medicine (Ne-515), Erasmus MC, PO Box 2040, 3000, CA, Rotterdam, The Netherlands. ${ }^{18}$ Edinburgh Imaging, Queen's Medical Research Institute, Edinburgh Bioquarter, 47 Little France Crescent, Edinburgh, UK. ${ }^{19}$ University Hospital Basel, Radiology and Nuclear Medicine, University of Basel, Petersgraben 4, CH-4031 Basel, Switzerland. ${ }^{20}$ European Society of Radiology, Am Gestade 1, 1010 Vienna, Austria.

Received: 3 May 2019 Accepted: 28 June 2019

Published online: 29 August 2019

\section{References}

1. Mercado CL (2014) BI-RADS update. Radiol Clin North Am. 52:481-487

2. Barentsz JO, Weinreb JC, Verma S et al (2016) Synopsis of the PI-RADS V2 guidelines for multiparametric prostate magnetic resonance imaging and recommendations for use. Eur Urol. 69:41-49
3. Hosny A, Parmar C, Quackenbush J, Schwartz LH, Aerts HJWL (2018) Artificial intelligence in radiology. Nat Rev Cancer. 18:500-510

4. Zacho HD, Nielsen JB, Afshar-Oromieh A et al (2018) Prospective comparison of (68)Ga-PSMA PET/CT, (18)F-sodium fluoride PET/CT and diffusion weightedMRI at for the detection of bone metastases in biochemically recurrent prostate cancer. Eur J Nucl Med Mol Imaging. 45:1884-1897

5. Boellaard R, Delgado-Bolton R, Oyen WJ et al (2015) FDG PET/CT: EANM procedure guidelines for tumour imaging: version 2.0. Eur J Nucl Med Mol Imaging. 42:328-354

6. O'Connor JP, Aboagye EO, Adams JE et al (2017) Imaging biomarker roadmap for cancer studies. Nat Rev Clin Oncol. 14:169-186

7. Zhuang M, Vallez Garcia D, Kramer GM et al (2018) Variability and repeatability of quantitative uptake metrics in [(18)F]FDG PET/CT imaging of non-small cell lung cancer: impact of segmentation method, uptake interval, and reconstruction protocol. J Nucl Med 60:600-607

8. Barrington SF, Kirkwood AA, Franceschetto A et al (2016) PET-CT for staging and early response: results from the Response-Adapted Therapy in Advanced Hodgkin Lymphoma study. Blood. 127:1531-1538

9. Hosny A, Parmar C, Quackenbush J, Schwartz LH, Aerts HJWL (2018) Artificial intelligence in radiology. Nat Rev Cancer 18:500-510

10. Trivedi SB, Vesoulis ZA, Rao $R$ et al (2017) A validated clinical MRI injury scoring system in neonatal hypoxic-ischemic encephalopathy. Pediatric radiology. 47:1491-1499

11. Machino M, Ando K, Kobayashi K et al (2018) Alterations in intramedullary T2-weighted increased signal intensity following laminoplasty in cervical spondylotic myelopathy patients: comparison between pre- and postoperative magnetic resonance images. Spine (Phila Pa 1976). 43:15951601

12. Chen CJ, Lyu RK, Lee ST, Wong YC, Wang LJ (2001) Intramedullary high signal intensity on T2-weighted MR images in cervical spondylotic myelopathy: prediction of prognosis with type of intensity. Radiology. 221: 789-794

13. Khanna D, Ranganath VK, Fitzgerald J et al (2005) Increased radiographic damage scores at the onset of seropositive rheumatoid arthritis in older patients are associated with osteoarthritis of the hands, but not with more rapid progression of damage. Arthritis Rheum. 52:2284-2292

14. Jaremko JL, Azmat O, Lambert RGW et al (2017) Validation of a knowledge transfer tool according to the OMERACT filter: does web-based real-time iterative calibration enhance the evaluation of bone marrow lesions in hip osteoarthritis? J Rheumatol. 44:1713-1717

15. Molyneux PD, Miller DH, Filippi M et al (1999) Visual analysis of serial T2weighted MRI in multiple sclerosis: intra- and interobserver reproducibility. Neuroradiology. 41:882-888

16. Stollfuss JC, Becker K, Sendler A et al (2006) Rectal carcinoma: high-spatialresolution MR imaging and T2 quantification in rectal cancer specimens. Radiology. 241:132-141

17. Barrington SF, Mikhaeel NG, Kostakoglu L et al (2014) Role of imaging in the staging and response assessment of lymphoma: consensus of the International Conference on Malignant Lymphomas Imaging Working Group. J Clin Oncol 32:3048-3058

18. Chernyak V Fowler KJ, Kamaya A et al (2018) Liver Imaging Reporting and Data System (LI-RADS) Version 2018: imaging of hepatocellular carcinoma in at-risk patients. Radiology 289:816-830

19. Elsayes KM, Hooker JC, Agrons MM et al (2017) 2017 version of LI-RADS for CT and MR imaging: an update. Radiographics. 37:1994-2017

20. Tessler FN, Middleton WD, Grant EG et al (2017) ACR thyroid imaging, reporting and data system (TI-RADS): white paper of the ACR TI-RADS committee. J Am Coll Radiol. 14:587-595

21. Panebianco V, Narumi Y, Altun E et al (2018) Multiparametric Magnetic Resonance Imaging for Bladder Cancer: Development of VI-RADS (Vesical Imaging-Reporting And Data System). Eur Urol. 74:294-306

22. Kitajima K, Tanaka U, Ueno $Y$ et al (2015) Role of diffusion weighted imaging and contrast-enhanced MRI in the evaluation of intrapelvic recurrence of gynecological malignant tumour. PLoS One. 10:e0117411

23. Cornelis F, Tricaud E, Lasserre AS et al (2015) Multiparametric magnetic resonance imaging for the differentiation of low and high grade clear cell renal carcinoma. Eur Radiol. 25:24-31

24. Martin MD, Kanne JP, Broderick LS, Kazerooni EA, Meyer CA (2017) LungRADS: pushing the limits. Radiographics. 37:1975-1993

25. Sabra MM, Sherman EJ (2017) Tumour volume doubling time of pulmonary metastases predicts overall survival and can guide the initiation of 
multikinase inhibitor therapy in patients with metastatic, follicular cellderived thyroid carcinoma. Cancer 123:2955-2964

26. Kadir T, Gleeson F (2018) Lung cancer prediction using machine learning and advanced imaging techniques. Transl Lung Cancer Res. 7:304-312

27. Eisenhauer EA, Therasse P, Bogaerts J et al (2009) New response evaluation criteria in solid tumours: revised RECIST guideline (version 1.1). Eur J Cancer 45:228-247

28. Yao GH, Zhang M, Yin LX et al (2016) Doppler Echocardiographic Measurements in Normal Chinese Adults (EMINCA): a prospective, nationwide, and multicentre study. Eur Heart J Cardiovasc Imaging. 17:512-522

29. Elgendy A, Seppelt IM, Lane AS (2017) Comparison of continous-wave Doppler ultrasound monitor and echocardiography to assess cardiac output in intensive care patients. Crit Care Resusc 19:222-229

30. Figueiredo CP, Kleyer A, Simon D et al (2018) Methods for segmentation of rheumatoid arthritis bone erosions in high-resolution peripheral quantitative computed tomography (HR-pQCT). Semin Arthritis Rheum. 47:611-618

31. Welsing PM, van Gestel AM, Swinkels HL, Kiemeney LA, van Riel PL (2001) The relationship between disease activity, joint destruction, and functional capacity over the course of rheumatoid arthritis. Arthritis Rheum. 44:2009-2017

32. Ødegård S1, Landewé R, van der Heijde D, Kvien TK, Mowinckel P, Uhlig T (2006) Association of early radiographic damage with impaired physical function in rheumatoid arthritis: a ten-year, longitudinal observational study in 238 patients. Arthritis Rheum. 54:68-75

33. Marcus CD, Ladam-Marcus V, Cucu C, Bouche O, Lucas L, Hoeffel C (2009) Imaging techniques to evaluate the response to treatment in oncology: current standards and perspectives. Crit Rev Oncol Hematol. 72:217-238

34. Levine ZH, Pintar AL, Hagedorn JG, Fenimore CP, Heussel CP (2012) Uncertainties in RECIST as a measure of volume for lung nodules and liver tumours. Med Phys. 39:2628-2637

35. Hawnaur JM, Johnson RJ, Buckley CH, Tindall V, Isherwood I (1994) Staging, volume estimation and assessment of nodal status in carcinoma of the cervix: comparison of magnetic resonance imaging with surgical findings. Clin Radiol. 49:443-452

36. Soutter WP, Hanoch J, D'Arcy T, Dina R, Mclndoe GA, DeSouza NM (2004) Pretreatment tumour volume measurement on high-resolution magnetic resonance imaging as a predictor of survival in cervical cancer. BJOG 111: 741-747

37. Jiang Y, You K, Qiu X et al (2018) Tumour volume predicts local recurrence in early rectal cancer treated with radical resection: a retrospective observational study of 270 patients. Int J Surg 49:68-73

38. Tayyab M, Razack A, Sharma A, Gunn J, Hartley JE (2015) Correlation of rectal tumour volumes with oncological outcomes for low rectal cancers: does tumour size matter? Surg Today. 45:826-833

39. Wagenaar HC, Trimbos JB, Postema S et al (2001) Tumour diameter and volume assessed by magnetic resonance imaging in the prediction of outcome for invasive cervical cancer. Gynecol Oncol. 82:474-482

40. Lee JW, Lee SM, Yun M, Cho A (2016) Prognostic value of volumetric parameters on staging and posttreatment FDG PET/CT in patients with stage IV non-small cell lung cancer. Clin Nucl Med. 41:347-353

41. Kurtipek E, Cayci M, Duzgun N et al (2015) (18)F-FDG PET/CT mean SUV and metabolic tumour volume for mean survival time in non-small cell lung cancer. Clin Nucl Med. 40:459-463

42. Meignan M, Cottereau AS, Versari A et al (2016) Baseline metabolic tumour volume predicts outcome in high-tumour-burden follicular lymphoma: a pooled analysis of three multicenter studies. J Clin Oncol. 34:3618-3626

43. Meignan M, Itti E, Gallamini A, Younes A (2015) FDG PET/CT imaging as a biomarker in lymphoma. Eur J Nucl Med Mol Imaging. 42:623-633

44. Kanoun S, Tal I, Berriolo-Riedinger A et al (2015) Influence of software tool and methodological aspects of total metabolic tumour volume calculation on baseline [18F]FDG PET to predict survival in Hodgkin lymphoma. PLoS One. 10:e0140830

45. Kostakoglu L, Chauvie S (2018) Metabolic tumour volume metrics in lymphoma. Semin Nucl Med. 48:50-66

46. Mori S, Oishi K, Faria AV, Miller MI (2013) Atlas-based neuroinformatics via MRl: harnessing information from past clinical cases and quantitative image analysis for patient care. Annu Rev Biomed Eng. 15:71-92

47. Cole JH, Poudel RPK, Tsagkrasoulis D et al (2017) Predicting brain age with deep learning from raw imaging data results in a reliable and heritable biomarker. Neuroimage. 163:115-124

48. Xu Y, Hosny A, Zeleznik R et al (2019) Deep learning predicts lung cancer treatment response from serial medical imaging. Clin Cancer Res. 25:3266-3275
49. Ferraioli G, Wong WW, Castera L et al (2018) Liver ultrasound elastography: an update to the world federation for ultrasound in medicine and biology guidelines and recommendations. Ultrasound Med Biol. 44:2419-2440

50. Lee SH, Chung J, Choi HY et al (2017) Evaluation of screening US-detected breast masses by combined use of elastography and color doppler US with B-Mode US in women with dense breasts: a multicenter prospective study. Radiology. 285:660-669

51. Woo S, Suh CH, Kim SY, Cho JY, Kim SH (2017) Shear-wave elastography for detection of prostate cancer: a systematic review and diagnostic metaanalysis. AJR Am J Roentgenol. 209:806-814

52. Du LJ, He W, Cheng LG, Li S, Pan YS, Gao J (2016) Ultrasound shear wave elastography in assessment of muscle stiffness in patients with Parkinson's disease: a primary observation. Clin Imaging. 40:1075-1080

53. Ramnarine KV, Garrard JW, Kanber B, Nduwayo S, Hartshorne TC, Robinson TG (2014) Shear wave elastography imaging of carotid plaques: feasible, reproducible and of clinical potential. Cardiovasc Ultrasound. 12:49

54. Dori A, Abbasi H, Zaidman CM (2016) Intramuscular blood flow quantification with power doppler ultrasonography. Muscle Nerve. 54:872-878

55. Regan EA, Hokanson JE, Murphy JR et al (2010) Genetic epidemiology of COPD (COPDGene) study design. COPD. 7:32-43

56. Sieren JP, Newell JD Jr, Barr RG et al (2016) SPIROMICS protocol for multicenter quantitative computed tomography to phenotype the lungs. Am J Respir Crit Care Med. 194:794-806

57. Keene JD, Jacobson S, Kechris K et al (2017) Biomarkers predictive of exacerbations in the SPIROMICS and COPDGene cohorts. Am J Respir Crit Care Med. 195:473-481

58. Andrade J, Schwarz M, Collard HR et al (2015) The Idiopathic Pulmonary Fibrosis Clinical Research Network (IPFnet): diagnostic and adjudication processes. Chest. 148:1034-1042

59. Washko GR, Diaz AA, Kim V et al (2014) Computed tomographic measures of airway morphology in smokers and never-smoking normals. J Appl Physiol (1985). 116:668-673

60. Jarjour NN, Erzurum SC, Bleecker ER et al (2012) Severe asthma: lessons learned from the National Heart, Lung, and Blood Institute Severe Asthma Research Program. Am J Respir Crit Care Med. 185:356-362

61. Schuhmann M, Raffy P, Yin Y et al (2015) Computed tomography predictors of response to endobronchial valve lung reduction treatment. Comparison with Chartis. Am J Respir Crit Care Med. 191:767-774

62. Van Der Molen MC, Klooster K, Hartman JE, Slebos DJ (2018) Lung volume reduction with endobronchial valves in patients with emphysema. Expert Rev Med Devices. 15:847-857

63. Salisbury ML, Lynch DA, van Beek EJ et al (2017) Idiopathic pulmonary fibrosis: the association between the adaptive multiple features method and fibrosis outcomes. Am J Respir Crit Care Med. 195:921-929

64. Goyal M, Menon BK, Derdeyn CP (2013) Perfusion imaging in acute ischaemic stroke: let us improve the science before changing clinical practice. Radiology. 266:16-21

65. Guo J, Wang C, Chan KS et al (2016) A controlled statistical study to assess measurement variability as a function of test object position and configuration for automated surveillance in a multicenter longitudinal COPD study (SPIROMICS). Med Phys. 43:2598

66. Rodriguez A, Ranallo FN, Judy PF, Fain SB (2017) The effects of iterative reconstruction and kernel selection on quantitative computed tomography measures of lung density. Med Phys. 44:2267-2280

67. Al-Mallah MH (2018) Coronary artery calcium scoring: do we need more prognostic data prior to adoption in clinical practice? JACC Cardiovasc Imaging. 11:1807-1809

68. Hoffmann U, Ferencik M, Udelson JE et al (2017) Prognostic value of noninvasive cardiovascular testing in patients with stable chest pain: insights from the PROMISE trial (Prospective Multicenter Imaging Study for Evaluation of Chest Pain). Circulation. 135:2320-2332

69. Newby DE, Adamson PD, Berry C et al (2018) Coronary CT angiography and 5-year risk of myocardial infarction. N Engl J Med. 379:924-933

70. Altenbernd J, Wetter A, Umutlu L et al (2016) Dual-energy computed tomography for evaluation of pulmonary nodules with emphasis on metastatic lesions. Acta Radiol 57:437-443

71. Lennartz S, Le Blanc M, Zopfs D et al (2019) Dual-energy CT derived iodine maps: use in assessing pleural carcinomatosis. Radiology. 290:796-804

72. Barker P, Golay X, Zaharchuk G (2013) Clinical perfusion MRI: techniques and applications. Cambridge University Press. 
73. Bittencourt LK, de Hollanda ES, de Oliveira RV (2016) Multiparametric MR imaging for detection and locoregional staging of prostate cancer. Top Magn Reson Imaging. 25:109-117

74. Lopci E, Franzese C, Grimaldi M et al (2015) Imaging biomarkers in primary brain tumours. Eur J Nucl Med Mol Imaging. 42:597-612

75. Bollineni VR, Kramer G, Liu Y, Melidis C, deSouza NM (2015) A literature review of the association between diffusion-weighted MRI derived apparent diffusion coefficient and tumour aggressiveness in pelvic cancer. Cancer Treat Rev 41:496-502

76. Galban CJ, Hoff BA, Chenevert TL, Ross BD (2017) Diffusion MRI in early cancer therapeutic response assessment. NMR Biomed. 30

77. Shukla-Dave A, Obuchowski NA, Chenevert TL et al (2018) Quantitative imaging biomarkers alliance (QIBA) recommendations for improved precision of DWI and DCE-MRI derived biomarkers in multicenter oncology trials. J Magn Reson Imaging. 49:e101-e121

78. Zeng Q, Shi F, Zhang J, Ling C, Dong F, Jiang B (2018) A modified tri-exponential model for multi-b-value diffusion-weighted imaging: a method to detect the strictly diffusion-limited compartment in brain. Front Neurosci 12:102

79. Langkilde F, Kobus T, Fedorov A et al (2018) Evaluation of fitting models for prostate tissue characterization using extended-range b-factor diffusionweighted imaging. Magn Reson Med. 79:2346-2358

80. Winfield JM, Tunariu N, Rata M et al (2017) Extracranial soft-tissue tumours: repeatability of apparent diffusion coefficient estimates from diffusionweighted MR imaging. Radiology 284:88-99

81. Taylor AJ, Salerno M, Dharmakumar R, Jerosch-Herold M (2016) T1 mapping: basic techniques and clinical applications. JACC Cardiovasc Imaging. 9:67-81

82. Toussaint M, Gilles RJ, Azzabou N et al (2015) Characterization of benign myocarditis using quantitative delayed-enhancement imaging based on Molli T1 mapping. Medicine (Baltimore). 94:e1868

83. Jurcoane A, Wagner M, Schmidt C et al (2013) Within-lesion differences in quantitative MRI parameters predict contrast enhancement in multiple sclerosis. J Magn Reson Imaging. 38:1454-1461

84. Katsube T, Okada M, Kumano S et al (2011) Estimation of liver function using T1 mapping on Gd-EOB-DTPA-enhanced magnetic resonance imaging. Invest Radiol. 46:277-283

85. Mozes FE, Tunnicliffe EM, Moolla A et al (2018) Mapping tissue water T1 in the liver using the MOLLI T1 method in the presence of fat, iron and BO inhomogeneity. NMR Biomed e4030

86. Adam SZ, Nikolaidis P, Horowitz JM et al (2016) Chemical shift MR imaging of the adrenal gland: principles, pitfalls, and applications. Radiographics. 36:414-432

87. Yang L, Ding Y, Rao $S$ et al (2017) Staging liver fibrosis in chronic hepatitis B with $\mathrm{T} 1$ relaxation time index on gadoxetic acid-enhanced MRI: comparison with aspartate aminotransferase-to-platelet ratio index and FIB-4. J Magn Reson Imaging 45:1186-1194

88. McDonald N, Eddowes PJ (2018) Multiparametric magnetic resonance imaging for quantitation of liver disease: a two-centre cross-sectional observational study. Sci Rep 8:9189

89. Serai SD, Obuchowski NA, Venkatesh SK et al (2017) Repeatability of MR elastography of liver: a meta-analysis. Radiology. 285:92-100

90. Tietze A, Blicher J, Mikkelsen IK et al (2014) Assessment of ischemic penumbra in patients with hyperacute stroke using amide proton transfer (APT) chemical exchange saturation transfer (CEST) MRI. NMR Biomed. 27: 163-174

91. Donahue MJ, Donahue PC, Rane S et al (2016) Assessment of lymphatic impairment and interstitial protein accumulation in patients with breast cancer treatment-related lymphedema using CEST MRI. Magn Reson Med. 75:345-355

92. Krishnamoorthy G, Nanga RPR, Bagga P, Hariharan H, Reddy R (2017) High quality three-dimensional gagCEST imaging of in vivo human knee cartilage at 7 Tesla. Magn Reson Med. 77:1866-1873

93. Lindeman LR, Randtke EA, High RA, Jones KM, Howison CM, Pagel MD (2018) A comparison of exogenous and endogenous CEST MRI methods for evaluating in vivo $\mathrm{pH}$. Magn Reson Med. 79:2766-2772

94. David S, Visvikis D, Roux C, Hatt M (2011) Multi-observation PET image analysis for patient follow-up quantitation and therapy assessment. Phys Med Biol. 56:5771-5788

95. MCDonald JE, Kessler MM, Gardner MW et al (2017) Assessment of total lesion glycolysis by (18)F FDG PET/CT significantly improves prognostic value of GEP and ISS in myeloma. Clin Cancer Res 23:1981-1987

96. Boellaard R (2009) Standards for PET image acquisition and quantitative data analysis. J Nucl Med 50(Suppl 1):11s-20s
97. Boellaard R, O'Doherty MJ, Weber WA et al (2010) FDG PET and PET/CT: EANM procedure guidelines for tumour PET imaging: version 1.0. Eur J Nucl Med Mol Imaging. 37:181-200

98. Kaalep A, Sera T, Rijnsdorp S et al (2018) Feasibility of state of the art PET/CT systems performance harmonisation. Eur J Nucl Med Mol Imaging. 45:13441361

99. Hoffmann R, von Bardeleben S, ten Cate F et al (2005) Assessment of systolic left ventricular function: a multi-centre comparison of cineventriculography, cardiac magnetic resonance imaging, unenhanced and contrast-enhanced echocardiography. Eur Heart J. 26:607-616

100. Donal E, Delgado V, Magne J et al (2017) Rational and design of EuroCRT: an international observational study on multi-modality imaging and cardiac resynchronization therapy. Eur Heart J Cardiovasc Imaging. 18:1120-1127

101. de Amorim Paiva CC, de Mello Junior CF, Guimaraes Filho HA et al (2014) Reproducibility of renal volume measurement in adults using 3-dimensional sonography. J Ultrasound Med 33:431-435

102. Janki S1, Kimenai HJAN, Dijkshoorn ML, Looman CWN, Dwarkasing RS, IJzermans JNM (2018) Validation of ultrasonographic kidney volume measurements: a reliable imaging modality. Exp Clin Transplant 16:16-22

103. Di Leo G, Di Terlizzi F, Flor N, Morganti A, Sardanelli F (2011) Measurement of renal volume using respiratory-gated MRI in subjects without known kidney disease: intraobserver, interobserver, and interstudy reproducibility. Eur J Radiol. 80:e212-e216

104. Veyrieres JB, Albarel F, Lombard JV et al (2012) A threshold value in Shear Wave elastography to rule out malignant thyroid nodules: a reality? Eur J Radiol. 81:3965-3972

105. Chang CY, Chang SJ, Chang SC, Yuan MK (2013) The value of positron emission tomography in early detection of lung cancer in high-risk population: a systematic review. Clin Respir J. 7:1-6

106. Martinez CH, Chen YH, Westgate PM et al (2012) Relationship between quantitative $C T$ metrics and health status and BODE in chronic obstructive pulmonary disease. Thorax. 67:399-406

107. Lynch DA, Moore CM, Wilson C et al (2018) CT-based visual classification of emphysema: association with mortality in the COPDGene study. Radiology. 288:859-866

108. Jacob J, Bartholmai BJ, Rajagopalan S et al (2017) Mortality prediction in idiopathic pulmonary fibrosis: evaluation of computer-based CT analysis with conventional severity measures. Eur Respir J. 49

109. Jovin TG, Saver JL, Ribo M et al (2017) Diffusion-weighted imaging or computerized tomography perfusion assessment with clinical mismatch in the triage of wake up and late presenting strokes undergoing neurointervention with Trevo (DAWN) trial methods. Int J Stroke. 12:641-652

110. van Riel SJ, Ciompi F, Jacobs C et al (2017) Malignancy risk estimation of screen-detected nodules at baseline $C T$ : comparison of the PanCan model, Lung-RADS and NCCN guidelines. Eur Radiol. 27:4019-4029

111. Heuvelmans MA, Walter JE, Vliegenthart $R$ et al (2018) Disagreement of diameter and volume measurements for pulmonary nodule size estimation in CT lung cancer screening. Thorax. 73:779-781

112. Matoba M, Tsuji H, Shimode $Y$, Nagata H, Tonami H (2018) Diagnostic performance of adaptive $4 \mathrm{D}$ volume perfusion $\mathrm{CT}$ for detecting metastatic cervical lymph nodes in head and neck squamous cell carcinoma. AJR Am J Roentgenology. 211:1106-1111

113. Zhang D, Xu A (2017) Application of dual-source CT perfusion imaging and MRI for the diagnosis of primary liver cancer. Oncol Lett. 14:5753-5758

114. Timmers JM, van Doorne-Nagtegaal HJ, Zonderland HM et al (2012) The Breast Imaging Reporting and Data System (BI-RADS) in the Dutch breast cancer screening programme: its role as an assessment and stratification tool. Eur Radiol 22:1717-1723

115. Zhang L, Tang M, Chen S, Lei X, Zhang X, Huan Y (2017) A meta-analysis of use of Prostate Imaging Reporting and Data System Version 2 (PI-RADS V2) with multiparametric MR imaging for the detection of prostate cancer. Eur Radiol. 27:5204-5214

116. van der Pol CB, Lim CS, Sirlin CB et al (2019) Accuracy of the liver imaging reporting and data system in computed tomography and magnetic resonance image analysis of hepatocellular carcinoma or overall malignancy-a systematic review. Gastroenterology. 156:976-986

117. deSouza NM, Winfield JM, Waterton JC et al (2018) Implementing diffusionweighted MRI for body imaging in prospective multicentre trials: current considerations and future perspectives. Eur Radiol 28:1118-1131

118. Hu Y, Tang H, Li H et al (2018) Assessment of different mathematical models for diffusion-weighted imaging as quantitative biomarkers for 
differentiating benign from malignant solid hepatic lesions. Cancer Med. https://doi.org/10.1002/cam4.1535. [Epub ahead of print]

119. Bao J, Wang X, Hu C, Hou J, Dong F, Guo L (2017) Differentiation of prostate cancer lesions in the transition zone by diffusion-weighted MRI. Eur J Radiol Open. 4:123-128

120. Nael K, Bauer AH, Hormigo A et al (2018) Multiparametric MRI for differentiation of radiation necrosis from recurrent tumour in patients with treated glioblastoma. AJR Am J Roentgenol 210:18-23

121. Bastiaannet $E$, Groen $H$, Jager PL et al (2004) The value of FDG-PET in the detection, grading and response to therapy of soft tissue and bone sarcomas; a systematic review and meta-analysis. Cancer Treat Rev. 30:83-101

122. van Dijk LV, Brouwer CL, van der Laan HP et al (2017) Geometric image biomarker changes of the parotid gland are associated with late xerostomia. Int J Radiat Oncol Biol Phys. 99:1101-1110

123. Lu SJ, Gnanasegaran G, Buscombe J, Navalkissoor S (2013) Single photon emission computed tomography/computed tomography in the evaluation of neuroendocrine tumours: a review of the literature. Nucl Med Commun 34:98-107

124. Ambrosini V, Campana D, Tomassetti P, Fanti S (2012) ${ }^{68} \mathrm{Ga}$-labelled peptides for diagnosis of gastroenteropancreatic NET. Eur J Nucl Med Mol Imaging. 39(Suppl 1):S52-S60

125. Maxwell JE, Howe JR (2015) Imaging in neuroendocrine tumours: an update for the clinician. Int J Endocr Oncol. 2:159-168

126. Gabriel M, Decristoforo C, Kendler D et al (2007) 68Ga-DOTA-Tyr3-octreotide PET in neuroendocrine tumours: comparison with somatostatin receptor scintigraphy and CT. J Nuclear Med 48:508-518

127. Park SY, Zacharias C, Harrison C et al (2018) Gallium 68 PSMA-11 PET/MR imaging in patients with intermediate- or high-risk prostate cancer. Radiology 288:495-505

128. Lambin P, Rios-Velazquez E, Leijenaar R et al (2012) Radiomics: extracting more information from medical images using advanced feature analysis. Eur J Cancer 48:441-446

129. Gillies RJ, Kinahan PE, Hricak H (2016) Radiomics: images are more than pictures, they are data. Radiology. 278:563-577

130. Aerts HJ, Velazquez ER, Leijenaar RT et al (2014) Decoding tumour phenotype by noninvasive imaging using a quantitative radiomics approach. Nat Commun 5:4006

131. Yip SS, Aerts HJ (2016) Applications and limitations of radiomics. Phys Med Biol. 61:R150-R166

132. O'Connor JP, Rose CJ, Waterton JC, Carano RA, Parker GJ, Jackson A (2015) Imaging intratumor heterogeneity: role in therapy response, resistance, and clinical outcome. Clin Cancer Res 21:249-257

133. Drukker K, Giger ML, Joe BN (2018) Combined benefit of quantitative threecompartment breast image analysis and mammography radiomics in the classification of breast masses in a clinical data set Radiology. 290:621-628

134. Lu M, Zhan X (2018) The crucial role of multiomic approach in cancer research and clinically relevant outcomes. EPMA J 9:77-102

135. Zhao B, Tan Y, Tsai WY et al (2016) Reproducibility of radiomics for deciphering tumour phenotype with imaging. Sci Rep. 6:23428

136. Peerlings J, Woodruff $H$, Winfield J et al (2019) Stability of radiomics features in apparent diffusion coefficient maps from a multi-centre test-retest trial. Sci Rep 9(1):4800

137. Kanis JA, Harvey NC, Cooper C, Johansson H, Oden A, McCloskey EV (2016) A systematic review of intervention thresholds based on FRAX : a report prepared for the National Osteoporosis Guideline Group and the International Osteoporosis Foundation. Arch Osteoporos 11:25

138. Cho I, Al'Aref SJ, Berger A et al (2018) Prognostic value of coronary computed tomographic angiography findings in asymptomatic individuals: a 6-year follow-up from the prospective multicentre international CONFIRM study. Eur Heart J. 39:934-941

139. Dweck MR, Chow MW, Joshi NV et al (2012) Coronary arterial 18F-sodium fluoride uptake: a novel marker of plaque biology. J Am Coll Cardiol 59:1539-1548

140. Pawade TA, Cartlidge TR, Jenkins WS et al (2016) Optimization and reproducibility of aortic valve 18F-fluoride positron emission tomography in patients with aortic stenosis. Circ Cardiovasc imaging. 9

141. Dweck MR, Jenkins WS, Vesey AT et al (2014) 18F-sodium fluoride uptake is a marker of active calcification and disease progression in patients with aortic stenosis. Circ Cardiovasc Imaging. 7:371-378

142. Joshi NV, Vesey AT, Williams MC et al (2014) 18F-fluoride positron emission tomography for identification of ruptured and high-risk coronary atherosclerotic plaques: a prospective clinical trial. Lancet 383:705-713
143. Forsythe RO, Dweck MR, McBride OMB et al (2018) ${ }^{18}$ F-sodium fluoride uptake in abdominal aortic aneurysms: the SoFIA ${ }^{3}$ study. J Am Coll Cardiol. 71:513-523

144. Mesaros S, Rocca M, Sormani M et al (2010) Bimonthly assessment of magnetisation transfer magnetic resonance imaging parameters in multiple sclerosis: a 14-month, multicentre, follow-up study. Mult Scler 16:325-331

145. Agosta F, Rovaris M, Pagani E, Sormani MP, Comi G, Filippi M (2006) Magnetisation transfer MRI metrics predict the accumulation of disability 8 years later in patients with multiple sclerosis. Brain 129:2620-2627

146. Rovaris M, Agosta F, Sormani MP et al (2003) Conventional and magnetisation transfer MRI predictors of clinical multiple sclerosis evolution: a medium-term follow-up study. Brain 126:2323-2332

147. Deantonio L, Caroli A, Puta E et al (2018) Does baseline [18F] FDG-PET/CT correlate with tumour staging, response after neoadjuvant chemoradiotherapy, and prognosis in patients with rectal cancer? Radiat Oncol 13:211

148. Pan L, Gu P, Huang G, Xue H, Wu S (2009) Prognostic significance of SUV on PET/CT in patients with esophageal cancer: a systematic review and metaanalysis. European journal of gastroenterology \& hepatology. 21:1008-1015

149. Lewis S, Besa C, Wagner M et al (2018) Prediction of the histopathologic findings of intrahepatic cholangiocarcinoma: qualitative and quantitative assessment of diffusion-weighted imaging. Eur Radiol. 28:2047-2057

150. Wang YT, Li YC, Yin LL, Pu H (2016) Can diffusion-weighted magnetic resonance imaging predict survival in patients with cervical cancer? A metaanalysis. Eur J Radiol. 85:2174-2181

151. Yu AC, Badve C, Ponsky LE et al (2017) Development of a combined MR fingerprinting and diffusion examination for prostate cancer. Radiology. 283: 729-738

152. Delgado AF, Delgado AF (2017) Discrimination between glioma grades II and III using dynamic susceptibility perfusion MRI: a meta-analysis. AJNR Am J Neuroradiol 38:1348-1355

153. Su C, Liu C, Zhao L et al (2017) Amide proton transfer imaging allows detection of glioma grades and tumor proliferation: comparison with Ki-67 expression and proton MR spectroscopy imaging. AJNR Am J Neuroradiol. 38(9):1702-1709

154. Hayano K, Shuto K, Koda K, Yanagawa N, Okazumi S, Matsubara H (2009) Quantitative measurement of blood flow using perfusion CT for assessing clinicopathologic features and prognosis in patients with rectal cancer. Dis Colon Rectum. 52:1624-1629

155. Win T, Miles KA, Janes SM et al (2013) Tumour heterogeneity and permeability as measured on the $C T$ component of PET/CT predict survival in patients with non-small cell lung cancer. Clinical cancer research : an official journal of the American Association for Cancer Research. 19:35913599

156. Lund KV, Simonsen TG, Kristensen GB, Rofstad EK (2017) Pretreatment latephase DCE-MRI predicts outcome in locally advanced cervix cancer. Acta Oncol 56:675-681

157. Fasmer KE, Bjornerud A, Ytre-Hauge S (2018) Preoperative quantitative dynamic contrast-enhanced MRI and diffusion-weighted imaging predict aggressive disease in endometrial cancer. Acta Radiol 59:1010-1017

158. Yu J, Xu Q, Huang DY et al (2017) Prognostic aspects of dynamic contrastenhanced magnetic resonance imaging in synchronous distant metastatic rectal cancer. Eur Radiol. 27:1840-1847

159. Wilson R, Devaraj A (2017) Radiomics of pulmonary nodules and lung cancer. Transl Lung Cancer Res. 6:86-91

160. Lee JW, Lee SM (2018) Radiomics in oncological PET/CT: clinical applications. Nucl Med Mol Imaging. 52:170-189

161. Kumar V, Gu Y, Basu S et al (2012) Radiomics: the process and the challenges. Magn Reson imaging. 30:1234-1248

162. Zhang Y, Oikonomou A, Wong A, Haider MA, Khalvati F (2017) Radiomicsbased prognosis analysis for non-small cell lung cancer. Sci Rep. 7:46349

163. Huang YQ, Liang CH, He L et al (2016) Development and validation of a radiomics nomogram for preoperative prediction of lymph node metastasis in colorectal cancer. J Clin Oncol. 34:2157-2164

164. Goldin JG, Kim GHJ, Tseng CH et al (2018) Longitudinal changes in quantitative interstitial lung disease on computed tomography after immunosuppression in the Scleroderma Lung Study II. Ann Am Thorac Soc. 15:1286-1295

165. Peacock AJ, Crawley S, McLure L et al (2014) Changes in right ventricular function measured by cardiac magnetic resonance imaging in patients receiving pulmonary arterial hypertension-targeted therapy: the EURO-MR study. Circ Cardiovasc Imaging. 7:107-114 
166. Steinhoff G, Nesteruk J, Wolfien M et al (2017) Cardiac function improvement and bone marrow response -: outcome analysis of the randomized PERFECT phase III clinical trial of intramyocardial CD133+ application after myocardial infarction. EBioMedicine 22:208-224.

167. Schwartz LH, Seymour L, Litiere S et al (2016) RECIST 1.1 - standardisation and disease-specific adaptations: perspectives from the RECIST Working Group. Eur J Cancer 62:138-145

168. Wahl RL, Jacene H, Kasamon Y, Lodge MA (2009) From RECIST to PERCIST: evolving considerations for PET response criteria in solid tumours. J Nucl Med 50(Suppl 1):122s-150s

169. Sormani MP, De Stefano N (2013) Defining and scoring response to IFNbeta in multiple sclerosis. Nat Rev Neurol. 9:504-512

170. Ostergaard M, Bird P, Gandjbakhch F et al (2015) The OMERACT MRI in arthritis working group - update on status and future research priorities. J Rheumatol. 42:2470-2472

171. Patel $P$, Baradaran $H$, Delgado D et al (2017) MR perfusion-weighted imaging in the evaluation of high-grade gliomas after treatment: a systematic review and meta-analysis. Neuro Oncol. 19:118-127

172. van Dijken BRJ, van Laar PJ, Holtman GA, van der Hoorn A (2017) Diagnostic accuracy of magnetic resonance imaging techniques for treatment response evaluation in patients with high-grade glioma, a systematic review and meta-analysis. Eur Radiol. 27:4129-4144

173. Aide N, Lasnon C, Veit-Haibach P, Sera T, Sattler B, Boellaard R (2017) EANM/ EARL harmonization strategies in PET quantification: from daily practice to multicentre oncological studies. Eur J Nucl Med Mol Imaging. 44:17-31

174. Maffione AM, Marzola MC, Capirci C, Colletti PM, Rubello D (2015) Value of ${ }^{18}$ F-FDG PET for predicting response to neoadjuvant therapy in rectal cancer: systematic review and meta-analysis. AJR Am J Roentgenology. 204: 1261-1268

175. Martens RM, Noij DP, Ali M et al (2019) Functional imaging early during (chemo)radiotherapy for response prediction in head and neck squamous cell carcinoma; a systematic review. Oral Oncol. 88:75-83

176. Cheson BD, Fisher Rl, Barrington SF et al (2014) Recommendations for initial evaluation, staging, and response assessment of Hodgkin and non-Hodgkin lymphoma: the Lugano classification. J Clin Oncol 32:3059-3068

177. Younes A, Hilden P, Coiffier B et al (2017) International Working Group consensus response evaluation criteria in lymphoma (RECIL 2017). Ann Oncol. 28:1436-1447

178. Dalm SU, Verzijlbergen JF, De Jong M (2017) Review: receptor targeted nuclear imaging of breast cancer. Int J Mol Sci 18

179. Bakht MK, Oh SW, Youn H, Cheon GJ, Kwak C, Kang KW (2017) Influence of androgen deprivation therapy on the uptake of PSMA-targeted agents: emerging opportunities and challenges. Nucl Med Mol Imaging 51:202-211

180. Hotker AM, Tarlinton L, Mazaheri Y et al (2016) Multiparametric MRI in the assessment of response of rectal cancer to neoadjuvant chemoradiotherapy: a comparison of morphological, volumetric and functional MRI parameters. Eur Radiol. 26:4303-4312

181. Partridge SC, Zhang Z, Newitt DC et al (2018) Diffusion-weighted MRI findings predict pathologic response in neoadjuvant treatment of breast cancer: the ACRIN 6698 Multicenter Trial. Radiology 289:618-627.

182. Hayano K, Okazumi S, Shuto K et al (2007) Perfusion CT can predict the response to chemoradiation therapy and survival in esophageal squamous cell carcinoma: initial clinical results. Oncol Rep. 18:901-908

183. O'Connor JP, Jackson A, Parker GJ, Roberts C, Jayson GC (2012) Dynamic contrast-enhanced MRI in clinical trials of antivascular therapies. Nat Rev Clin Oncol. 9:167-177

184. Choi H, Charnsangavej C, Faria SC et al (2007) Correlation of computed tomography and positron emission tomography in patients with metastatic gastrointestinal stromal tumour treated at a single institution with imatinib mesylate: proposal of new computed tomography response criteria. J Clin Oncol 25:1753-1759

185. El Alaoui-Lasmaili K, Faivre B (2018) Antiangiogenic therapy: markers of response, "normalization" and resistance. Crit Rev Oncol Hematol. 128: $118-129$

186. Sheikhbahaei S, Mena E, Yanamadala A et al (2017) The value of FDG PET/ $C T$ in treatment response assessment, follow-up, and surveillance of lung cancer. AJR Am J Roentgenol. 208:420-433

187. Goense L, van Rossum PS, Reitsma JB et al (2015) Diagnostic performance of ${ }^{18}$ F-FDG PET and PET/CT for the detection of recurrent esophageal cancer after treatment with curative intent: a systematic review and metaanalysis. J Nucl Med 56:995-1002
188. Sullivan DC, Obuchowski NA, Kessler LG et al (2015) Metrology standards for quantitative imaging biomarkers. Radiology. 277:813-825

189. Waterton JC, Pylkkanen $L$ (2012) Qualification of imaging biomarkers for oncology drug development. Eur J Cancer 48:409-415

\section{Publisher's Note}

Springer Nature remains neutral with regard to jurisdictional claims in published maps and institutional affiliations.

\section{Submit your manuscript to a SpringerOpen ${ }^{\circ}$ journal and benefit from:}

- Convenient online submission

- Rigorous peer review

- Open access: articles freely available online

- High visibility within the field

- Retaining the copyright to your article

Submit your next manuscript at $\boldsymbol{\nabla}$ springeropen.com 